\title{
The Chemical Defense Ecology of Marine Unicellular Plankton: Constraints, Mechanisms, and Impacts
}

\author{
GORDON V. WOLFE* \\ Shannon Pt. Marine Center, Western Washington University, 1900 Shannon Pt. Rd., \\ Anacortes, Washington 98221
}

\begin{abstract}
The activities of unicellular microbes dominate the ecology of the marine environment, but the chemical signals that determine behavioral interactions are poorly known. In particular, chemical signals between microbial predators and prey contribute to food selection or avoidance and to defense, factors that probably affect trophic structure and such large-scale features as algal blooms. Using defense as an example, I consider physical constraints on the transmission of chemical information, and strategies and mechanisms that microbes might use to send chemical signals. Chemical signals in a low Re, viscosity-dominated physical environment are transferred by molecular diffusion and laminar advection, and may be perceived at nanomolar levels or lower. Events that occur on small temporal and physical scales in the "near-field" of prey are likely to play a role in cell-cell interactions. On the basis of cost-benefit optimization and the need for rapid activation, I suggest that microbial defense system strategies might be highly dynamic. These strategies include compartmented and activated reactions, utilizing both pulsed release of dissolved signals and contact-activated signals at the cell surface. Bioluminescence and extrusome discharge are two visible manifestations of rapidly activated microbial defenses that may serve as models for other chemical reactions as yet undetected due to the technical problems of measuring transient chemical gradients around single cells. As an example, I detail an algal dimethylsulfoniopropionate (DMSP) cleavage reaction that appears to deter protozoan feeding
\end{abstract}

\footnotetext{
Received 6 April 1999; accepted 16 November 1999.

* Current address: Dept. of Biological Sciences, California State University, Chico, Chico, California 95929-0515. E-mail: gwolfe2@csuchico.edu

This paper was originally presented at a symposium titled Chemical Communication and Ecology. The symposium, which was held in San Diego, California, on 30 December 1998, was invited by the Western Society of Naturalists as part of its annal meetings.
}

and explore it as a possible model for a rapidly activated, short-range chemical defense system. Although the exploration of chemical interactions among planktonic microbes is in its infancy, ecological models from macroorganisms provide useful hints of the complexity likely to be found.

\section{Introduction}

In contrast to the multicellular organisms whose chemical ecology is adapted to turbulent environments of high or intermediate Reynolds number, planktonic marine microbes that are generally well below $1 \mathrm{~mm}$ in size are the focus of this paper. This extremely diverse and ecologically important group includes mostly unicellular prokaryotes (bacteria and archaea) and eukaryotes (protists: algae and protozoa) that range in size from $<1$ to $200 \mu \mathrm{m}$ (Fig. 1). This realm is dominated by viscous forces, and chemical information is transmitted by "simple" diffusion and advective laminar flow. But although the behavioral and chemosensory abilities of unicellular microbes have been known for nearly a century (Jennings, 1906; Schaeffer, 1910) and the general physical, chemical, and molecular regulation of microbial signaling and behavior have been recognized for decades (Carlile, 1975; Berg and Purcell, 1977; Levandowsky and Hauser, 1978; Aaronson, 1981; Van Houten et al., 1981), they remain poorly understood. Recent calculations suggest that microbial chemosensory adaptations to diffusive environments may be even more sophisticated than previously thought (Dusenbery, 1998). This realm also remains largely unexplored experimentally due to profound technical difficulties of observation.

In this paper, I review and synthesize physiological information from model cell-biology systems with physical limitations on microbial signaling in aqueous environments, focusing on food selection and chemical defense as an example of the potentially complex chemical ecology of 


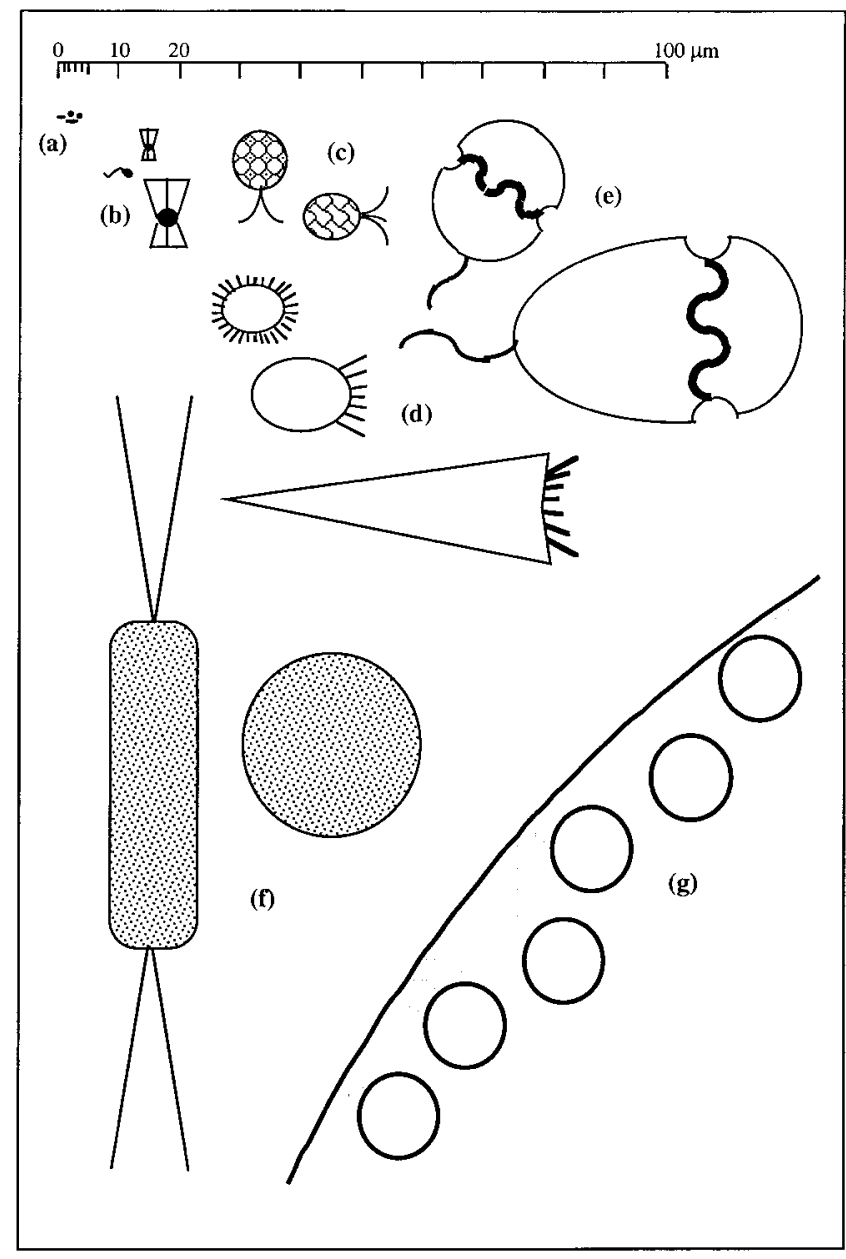

Figure 1. Size range of unicellular marine plankton. The illustration is purely schematic and indicates just a few major groups, most of which include both autotrophic and heterotrophic taxa. Included are bacteria and prochlorophytes (a); nanoflagellates, including heterotrophs (b) and autotrophic haptophytes (c); oligotrichous, hypotrichous, and tintinnid ciliates (d); dinoflagellates (e); and diatoms (f). Also shown for comparison is a millimeter-scale colony of the nanoflagellate Phaeocystis pouchetii with cells arranged at the periphery $(\mathrm{g}) ; 200 \mu \mathrm{m}$ is a rough upper size limit for most marine protists, and a lower limit for metazoan grazers. However, many cells have projections of considerable complexity that greatly increase their effective size, such as choanoflagellate feeding baskets (b) or diatom spines (f).

marine plankton. I then explore microbial defense-system strategies and signal mechanisms as limited by physical and physiological potential. These suggest that dynamic events which occur on small temporal and physical scales are likely to be important, although their measurement poses great technical challenges. I detail a reaction hypothesized to affect protozoan feeding selectivity that might serve as a model for rapidly activated, short-range microbial deterrence systems. Finally, I briefly examine trophic and evolutionary implications of planktonic chemical defense, and suggest that ecological models from macroorganisms will provide useful hints about the probable complexity of in- teractions. The literature holds many fascinating glimpses into the complex world of microbial signaling, spread widely among many disciplines such as fluid physics, chemical ecology, microbiology, immunology, biochemistry, molecular biology, and oceanography. I will be able to touch on many aspects of these topics only briefly, and have tried to provide a recent and somewhat comprehensive list of sources for further information.

\section{Rationale: the microbial biosphere}

Microbes dominate evolutionary history: for over half of Earth's existence, the biosphere was entirely microbial (Knoll and Lipps, 1993; Roberts et al., 1996). This reign led to the evolution of vast genetic diversity (Barns and Nierzwicki-Bauer, 1997; Pace, 1997); for example, prokaryotic (bacterial and archaeal) metabolic pathways affect all major biogeochemical cycles and led to the oxidation of the Earth's surface (Falkowski and Raven, 1997; Fenchel et al., 1998).

In the present-day biosphere, microbes are most obviously the exclusive colonizers of extreme environments (Karl, 1995; Gross, 1998), but are surprisingly important to global productivity. The oceans are microbially dominated ecosystems (Sherr and Sherr, 1991), and although marine plankton constitute less than $0.5 \%$ of global biomass, they contribute nearly $50 \%$ of global net primary production (Field et al., 1998). In most of the ocean, nutrient concentrations are low, and osmotrophs have evolved towards small sizes to optimize nutrient uptake. Therefore, much of marine primary production is dominated by pico- and nonoplankton less than $20 \mu \mathrm{m}$ in size. These organisms are eaten primarily by protozoan grazers, which are also the major grazers of marine bacteria (Sherr and Sherr, 1994), and are therefore important recyclers of nutrients in the upper oceans (Strom, 2000). They are also critical trophic links between their prey and larger metazoan grazers (Fessenden and Cowles, 1994), forming the base of the marine food web (Pomeroy, 1992).

\section{Microbial signaling}

A signal is a directed communication: the transfer of information between two organisms via a biogenic stimulus that can be perceived by a sensory system and evoke an adaptive response (Dusenbery, 1992). Signals received at the cell surface are conveyed intracellularly by several major mechanisms, including ion-channel-linked receptors, $\mathrm{G}$ protein-linked receptors and enzyme-linked receptors (Van Houten, 1994). $\mathrm{Ca}^{2+}$ and cyclic AMP are important molecules in mediating signal transduction and may also act externally to the cell (O'Day, 1990; Louis et al., 1993). For example, mechanosensors in ciliates are driven by $\mathrm{Ca}^{2+}$ ion currents (Hennessey, 1989), resulting in excitatory action potential waves that pass over the surface of the cell, caus- 
ing rapid depolarization and hyperpolarization and leading to synchronized ciliary motion for movement (FebvreChavalier et al., 1989).

Protozoa also have cell-surface signal receptors that recognize vertebrate and plant hormones as varied as polypeptides, cytokines, indolacetic acid, and opiates (Csaba, 1996). These vertebrate and plant signal molecules can promote chemotaxis (Köhidai et al., 1994), phagocytosis (Rabinovitch and De Stefano, 1971; Renaud et al., 1995), and other responses (Kovaács et al., 1997). Protozoa also produce hormone molecules (LeRoith et al., 1982) that may interact with cell receptors (Marino and Wood, 1993). The adaptive significance for these signaling molecules in protists is poorly understood, but evolution of such signals and their receptors probably led to cellular hormonal systems in higher organisms (Carr, 1989). Almost nothing is known about such signaling in most environmentally important protists, especially in marine environments.

Receptor sensitivities and reaction times depend on diffusion of signal molecules and binding strengths. The signal-to-noise ratio $(\mathrm{S} / \mathrm{N})$ scales as $(\mathrm{tDCR})^{0.5}$ (Dusenbery, 1992), where $R$ is the effective receptor radius, $C$ the signal concentration for a signal with diffusion constant $\mathrm{D}$, and $\mathrm{t}$ the integration time. For $\mathrm{S} / \mathrm{N} \sim 1, \mathrm{t} \sim 0.1 \mathrm{~s}, \mathrm{R} \sim 0.1 \mu \mathrm{m}$ and $\mathrm{D} \sim 10^{-6} \mathrm{~cm}^{2} \mathrm{~s}^{-1}, \mathrm{C}$ is about $10^{-9} M$, a value consistent with observations. Receptor sensitivity-the minimal concentration for detectable $\mathrm{S} / \mathrm{N}$ - scales as $(\mathrm{Rt})^{-2}$. Since small cells cannot increase receptor size, longer integration times may be used to increase sensitivity (Dusenbery, 1992).

\section{Behavioral responses to signals}

Signaling between cells in multicellular organisms encompasses such activities as cell movement and adhesion, development, differentiation, and programmed cell death (apoptosis); electrochemical signal propagation and cellular signaling networks; and predator-prey (phagocytotic) interactions. Although typically studied in vertebrate systems, nearly all probably originated in unicellular microbes (Carlile, 1975; Kurjan and Taylor, 1993; Csaba and Müller, 1996) and have been studied in detail for a few protozoan models (Paramecium, Tetrahymena, Dictyostelium [Loomis, 1982; Gall, 1986; Devreotes, 1989]).

Although microorganisms lack the specialized physical development of multicellular animals and plants, they have complex and sophisticated sensory and behavioral adaptations to their environment (Jennings, 1906). Microbes respond to stimuli by development, attachment (intraspecific) or endocytosis (interspecific), or movement. Developmental changes (Fig. 2a) are intraspecific and include mating, encystment, and aggregation or colony formation; they often operate by contact-mediated recognition processes (Calleja, 1984). A model system is the cellular slime mold Dictyostelium, explored for its insights into the evolution of mul-
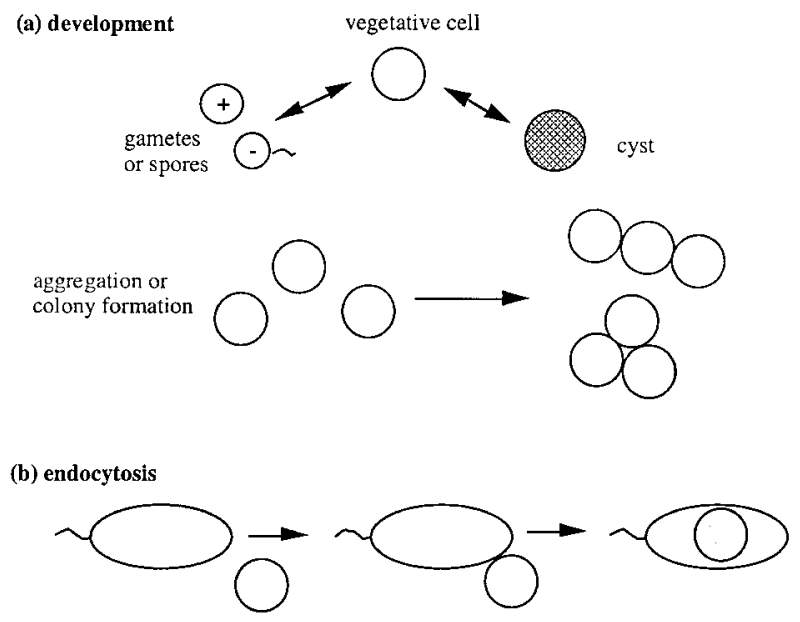

(c) movement

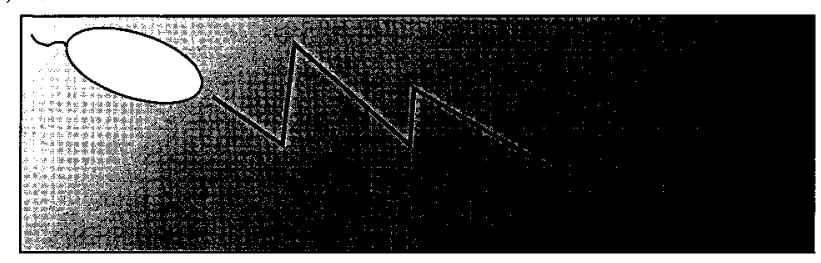

Figure 2. General microbial responses to chemical signals. (a) Developmental (life-cycle) responses include sexual reproduction or encystment; (b) attachment responses include aggregation or colony formation (intraspecific) or endocytosis (intra- or interspecific); (c) movement responses to chemical gradients include changes in swimming speed (taxis) or frequency of turning (kinesis).

ticellularity (Loomis, 1982). Endocytosis (Fig. 2b) is usually interspecific, but the close relation between phagocytosis and mating (sex) has long been noted (Margulis and Sagan, 1987). Phagocytosis can be mediated by prey-excreted or prey-surface molecules (Rabinovitch and De Stefano, 1971; Brown et al., 1975; Vogel et al., 1980; Wright and Silverstein, 1986; Kiersnowska et al., 1988). Contact and recognition of prey often seem to be distinct processes, although this is poorly understood (Peck, 1985; Ricci et al., 1996).

Protist movements include swimming, surface gliding (benthic diatoms, desmids), or crawling (ameboid movement due to protoplasmic streaming). Here I focus on swimming, the dominant mode among plankton. The two main marine protozoan groups are flagellates and ciliates (Fenchel, 1987), whose propulsion systems operate by similar mechanisms. Flagellates use one or more flagella (= whip; also termed undulopodia [Margulis et al., 1990] to differentiate them from the structurally different bacterial flagella). Ciliated cells are covered in an array of shorter cilia (= hair); metachronous depolarization waves passing over the ciliate cell cause coordinated ciliary movement for motion (Hennessey, 1989; Clark et al., 1993). Protozoa typically swim at about $200 \mu \mathrm{m} \mathrm{s}^{-1}$ (flagellates) to 1000 
$\mu \mathrm{m} \mathrm{s}^{-1}$ (ciliates). Given body lengths of less than $200 \mu \mathrm{m}$, most microbes thus operate in a viscosity-dominated realm $(\operatorname{Re} \ll 1)$ where fluid motions are completely reversible in time (Purcell, 1977). Although swimming speed increases with cell size, power requirements increase more rapidly than propulsive force, limiting speeds for larger cells (Fenchel, 1987, p. 20). Protists are less affected by random thermal (Brownian) movement than are smaller bacteria, and they can orient and position, often swimming in helical motions that may help in orientation (Crenshaw, 1992).

\section{The Chemical Dynamics of Microbial Trophic Interactions}

\section{Finding and selecting prey}

In most marine waters the plankton constitute an extremely dilute suspension, usually less than $10 \mathrm{ppm}$ by volume. Therefore, a major challenge for predatory microbes is finding prey sufficient to maintain (rapid) growth, and detection of prey at a distance would seem to be an advantage in locating food (Buskey and Stoecker, 1988). Many protists show responses to chemical gradients in space or time. Chemotaxis is stimulus-oriented (directed) movement, whereas chemokinesis is stimulus-induced movement without directional orientation. The latter is much more common; it includes both orthokinesis (change in linear velocity) and klinokinesis (change in rate of turning, Fig 2c) and is based on adaptation mechanisms (Machemer and Teunis, 1996).

There are several major feeding modes. Raptorial feeders (Fenchel, 1987) directly intercept prey following random contact. Collision-based prey capture is determined by the effective prey cross-section, which scales as $S_{p}=\left(r_{g}+r_{p}\right)^{2}$ where $r_{g}$ and $r_{p}$ denote the radii of spherical grazer and prey. Grazers encounter prey at a rate of $\mathrm{E}=\pi / 3 \mathrm{~S}_{\mathrm{p}} \mathrm{N}_{\mathrm{p}}\left(3 \mathrm{v}_{\mathrm{g}}{ }^{2}+\right.$ $\left.\mathrm{v}_{\mathrm{p}}{ }^{2}\right) / \mathrm{v}_{\mathrm{g}}$ where $\mathrm{N}_{\mathrm{p}}$ is the prey density and $\mathrm{v}$ the speeds (Gerritsen and Strickler, 1977); the frequency of encounters thus increases with relative speed (prey speeds are often small compared to grazers). Filter feeders, the other major feeding mode typified by ciliates and some flagellates, generate feeding currents that bring prey towards grazer cells. Particle capture is determined by particle size, the shear fields produced by feeding currents, and capture structures (Fenchel, 1980; Jonsson, 1986; Monger and Landry, 1991).

However they capture prey, all predators need to obtain high-quality nutrients and nutritional balance while avoiding toxic prey. Although acute responses that result from ingestion of a small number of highly toxic prey (death, reduced growth or reproductive rates) have been noted in some laboratory studies (Sykes and Huntley, 1987; Hansen, 1995), it is not clear how these operate in natural populations. However, subacute effects, which affect feeding behavior by stimulating avoidance or rejection of protected prey, are probably as or more important. There is increasing evidence that prey selection is based on chemical cues determined during prey capture, handling, or ingestion, leading to rejection following prey capture (e.g., Taniguchi and Takeda, 1988; Stoecker et al., 1995), but these cues are little understood at present. Such cues are not necessarily limited to highly toxic cells or compounds (Stoecker et al., 1981; Rassoulzadegan and Fenaux, 1984; DeMott, 1986; Cowles et al., 1988; Sanders, 1988; Van Donk et al., 1997).

\section{Defense problems and strategies}

How might a single cell defend itself against predation? Constitutive toxicants are self-hazardous and costly to maintain in the face of shifting predation risk. It is also clear that for unicellular organisms, which have no tissue to sacrifice, repelling or discouraging attack is better than post-ingestion toxicity. Induced defense responses-phenotypic modification in response to predator cues-are widespread among macroorganisms and increasingly recognized as important defense strategies (Karban and Baldwin, 1997; Tollrian and Harvell, 1999). These changes are often slow, requiring gene transcription and growth or development, and typically occur on time scales of hours to days. Although examples of such responses exist among planktonic microbes (ciliates [Kusch, 1993; Kusch, 1995]), the short time scales of microbial encounters suggest more immediate deterrents. Here, I consider several strategies that may have adaptive advantages to microbial chemical defense.

Compartmentation. One general strategy for sequestering self-toxic compounds is compartmentation (Fowden and Lea, 1979). Large organisms may have specialized tissues or organs for safely containing toxicants (Hefetz and Blum, 1978; Rossini et al., 1997). In vascular plants, vacuoles often serve as compartments to concentrate toxins (Wagner, 1978; Wink, 1997). All eukaryotic cells have highly compartmented organelles and many produce highly toxic metabolites (Hall and Strichartz, 1990; Plumley, 1997). Socalled harmful algal bloom (HAB) taxa produce paralytic toxicants that inhibit metazoan nerve conduction (Cembella, 1998), such as the saxitoxins (Hall et al., 1990). Although these toxins may function as grazing deterrents (Turner and Tester, 1997; Turner et al., 1998) or allelopathic compounds (Dakshini and Dakshini, 1994; Subba Rao et al., 1995; Windust et al., 1996; Sugg and VanDolah, 1999), evidence is contradictory, and their ecological functions are poorly understood. However, most appear to be produced constitutively and may pose a hazard to the algae that synthesize them. Compartmentation may reduce autotoxicity; saxitoxins in Gonyaulax and okadaic acid in Prorocentrum localize to chloroplasts (Anderson and Cheng, 1988; Zhou and Fritz, 1994).

Activated reactions. Compartmentation also is used in "activated' reactions," whereby a grazer-initiated signal causes a rapid reaction that produced a feeding deterrent. 
Examples of such systems in macroalgae (Paul and van Alstyne, 1992) and vascular plants include some of the best-known plant defense systems, including hydrolysis of glucosinolates (Newman et al., 1992) and cyanogenesis (Jones et al., 1978). These generally appear to be mixing reactions initiated when grazing injury disrupts compartmented enzyme-substrate systems. Such systems are elegant solutions to minimizing self-toxicity and the energetic cost of defense capability. Since microbes typically operate on short time scales, and predator-prey interactions may occur in seconds, rapid defense systems or strategies ought to be favored evolutionarily, but no direct observations of activated chemical systems in unicellular organisms have yet been reported. This is probably due to the technical difficulties of detecting transient and small-scale chemical gradients around single cells. Only recently has a first report even demonstrated the production of a compartmented mixing reaction in a phospholipid bilayer system similar in size to a eukaryotic nanoplankter cell (Chiu et al., 1999).

However, several observable examples of compartmented, rapidly activated microbial defense reactions might serve as conceptual models for the rapid production of chemical signals. One is mechanically stimulated bioluminescence, produced by many marine dinoflagellates (e.g., Pyrocystis, Pyrodinium, Gonyaulax, or Noctiluca [Johnson et al., 1985; Anderson et al., 1988]). In these organisms, light is emitted when the enzyme luciferase oxidizes a substrate, luciferin, contained in small vesicles called scintillons. Luciferin is normally prevented from reacting by attachment to a luciferin-binding protein; mechanical distortion of the cell plasma membrane generates an electrical action potential that traverses the cell in less than a microsecond (Nicolas et al., 1975), creating an influx of protons that releases luciferin for oxidation. The result is a nearsynchronous sequence of scintillon microflashes that collectively appear as a pulse of light. The reaction functions for defense against metazoan grazers, acting as a "burglar alarm" to attract predators of the grazers (Esaias and Curl Jr., 1972; White, 1979; Buskey and Swift, 1985; Mensinger and Case, 1992; Abrahams and Townsend, 1993).

The other example involves exocytosis, the release of chemicals sequestered inside vesicles to the cell exterior, by vesicle fusion with the cell plasma membrane. Extrusomes are organelles common to most ciliates and dinoflagellates (Bouck and Sweeney, 1966; Dodge and Greuet, 1987; Görtz, 1988), and also found in some other taxa, that explosively release toxicysts, trichocysts, or nematocysts from the cell surface. This release is triggered by mechanical distortion of the cell surface or by chemical (polyamino) cues (Plattner et al., 1985) mediated by GTP-binding proteins (Peterson, 1991). Nematocysts and toxicysts are used to secure and immobilize prey (Wesenberg and Antipa, 1970), but the role of trichocysts has long been a puzzle (Mast, 1906; Haacke-Bell et al., 1990). Recent evidence suggests that trichocyst discharge causes swimming reversal in Paramecium (Harumoto, 1994) and thus functions for defense, physically driving prey ciliates away from predators (Harumoto and Miyake, 1991; Knoll et al., 1991). A particularly fascinating example is the hypotrich ciliate $E u$ plotidium itoi. This species carries symbiotic epibionts termed epixenosomes (Rosati, 1999) that contain extrusomes (Rosati et al., 1993). Euplotidium cells lacking epixenosomes are much more susceptible to predation by the ciliate Litonotus, suggesting that these organelles function for defense of the host cell (Rosati et al., 1999).

Although extrusomes are visible polymerization reactions, triggered exocytosis may also be a fundamental method of chemical communication among microbes. Exocytotic reactions are a widespread and highly conserved method of cellular communication within multicellular organisms and occur over time scales ranging from minutes to microseconds (Almers, 1990; Burgoyne and Morgan, 1993). They include such diverse phenomena as histamine release by mast cells following inflammation (Gomperts et al., 1994), neutrophil phagocytosis (Suzaki et al., 1997), sperm acrosomal and egg activation reactions during fertilization (Jaffe, 1985; Tilney, 1985), and neurotransmitter release at nerve synapses (von Gersdorff and Matthews, 1994).

Multifunctional systems. Compartmented and activated reactions not only are rapid but may be very efficient energetically, since no protein synthesis is required for initiation. Another strategy to improve efficiency is to use defense molecules for multiple purposes. For example, tetrodotoxin, the nerve-impulse inhibitor produced by the pufferfish $F u g u$, also functions as a mating pheromone (Matsumura, 1995). This compound is concentrated in gametes that otherwise would be especially vulnerable to predation. Ciliate extrusomes probably play multiple roles: Paramecium trichocysts aid in both food capture and escape from predation (Wesenberg and Antipa, 1970; Harumoto and Miyake, 1991).

Carr (1988) pointed out that many biochemical intermediates, such as amino acids, nucleic acids, and fatty acids, and their derivatives, are often in the high millimolar range inside cells. However, the background concentrations of these labile molecules in aqueous environments are nanomolar or below. Within this enormous concentration range, many such molecules show chemosensory activity for a variety of organisms. Therefore, active release or conversion of concentrated solute pools may provide easily detectable signals to potential predators, while utilizing precursor molecules that are used for other processes and not costly in the absence of predation. The costs of defense in planktonic microbes have only recently been addressed (Kusch and Kuhlmann, 1994) and warrant further study. 
Table 1

Chemical defense signal mechanisms; chemical signals can include both trophic and toxic compounds

\begin{tabular}{|c|c|c|c|}
\hline & Excreted signal & Contact signal & Post-ingestion signal \\
\hline Molecules & $\begin{array}{l}\text { Small molecules but varied structures: organic } \\
\text { and amino acids, sugars, short-chain lipids } \\
\text { and derivatives }\end{array}$ & $\begin{array}{l}\text { Glycoproteins, glycolipids, } \\
\text { polypeptides }\end{array}$ & Varied: toxicants or toxins \\
\hline Signal properties & $\begin{array}{l}\text { Aqueous solubility, diffusivity, lability, } \\
\text { toxicity }\end{array}$ & Specificity, toxicity & Toxicity or concentration \\
\hline Signal location & Aqueous environment & Cell surface & Cell interior \\
\hline $\begin{array}{l}\text { Effect or mode } \\
\text { of action }\end{array}$ & Negative kinesis/taxis: repellent & $\begin{array}{l}\text { Release following capture: } \\
\text { deterrent }\end{array}$ & $\begin{array}{l}\text { Subsequent inhibition of feeding or toxicity, } \\
\text { reduced digestability or growth efficiency }\end{array}$ \\
\hline Benefit level & $\begin{array}{l}\text { Individual or population, including } \\
\text { competitors }\end{array}$ & Individual & Population of genets \\
\hline
\end{tabular}

\section{Signal mechanisms}

I next consider possible strategies for conveying chemical deterrence signals, in the order they might be perceived by a grazer (Table 1). They include signals excreted to the environment, cell-surface signals, and internal toxins that act following ingestion. Long-range chemical signals may act as repellents, preventing the initiation of feeding by causing the predator to orient away from a potential prey; closer-range signals may act as deterrents, repelling predators that have attempted to feed (Lindstedt, 1971). Signals might be presented continuously or activated in response to some trigger (Fig. 3).

The mechanisms of chemical signaling by microbes, though obscure, must be considered in the context of physical and physiological constraints on signal production and reception. I consider them in the general context of plankton ecology and physiology. This discussion is necessarily conceptual since the technical difficulties of measuring cell-cell chemical interactions in vivo are profound; we cannot yet detect the events that may occur in the brief instant when predator and prey meet. How do microbes convey chemical signals? What kinds of infochemicals are used by marine plankton?

Excreted signals. Low-molecular-weight metabolites include photosynthetic sugars, amino acids and derivatives, and also polypeptides and even some small lipids and proteins. Although polar compounds have relatively low membrane permeabilities, Bjørnson (1988) has suggested that small cells with large surface-to-volume ratios may unavoidably "leak" metabolites at potentially high rates. Whether such leakage is passive or active is poorly known; phototrophs in particular may actively excrete compounds to release excess reducing power under high irradiance, although the adaptive purpose is still contentious (Wood and van Valen, 1990). Therefore, as they approach prey, predators swim through gradients of excreted metabolites
(Fig. 3a), a zone termed the phycosphere (Sieburth, 1968; Bell and Mitchell, 1972), which may serve to advertise the presence of the prey. Some protozoa can clearly detect excreted prey metabolites (Hauser et al., 1975a; Levandowsky and Hauser, 1978; Van Houten et al., 1981; Bennett et al., 1988; Verity, 1988), and although movement for chemical searches requires constant energy in the noninertial low Re environment, swimming costs are a trivial fraction of protozoan energy budgets (Fenchel, 1987). Whether protozoan grazers can use gradients to locate individual prey cells is less certain (Jackson, 1987).

It would seem advantageous for prey to also exude signal deterrents to keep grazers at a distance and thus avoid any possibility of damage during handling. However, because the time for molecular diffusion scales as $\mathrm{r}^{2} / 6 \mathrm{D}$ and $\mathrm{D}<10^{3}$ $\mu \mathrm{m}^{2} \mathrm{~s}^{-1}$, this limits rapid signal transport to "near-field" regions within a few to a hundred micrometers. Beyond, turbulence at the millimeter scale also dissipates microzone gradients, although the impact is still controversial (Mitchell et al., 1985; Alldredge and Cohen, 1987). (Much consideration has focused on detection of these microzones by bacteria, whose physical and physiological constraints and mechanisms may be very different from those of larger protozoa [Bowen et al., 1993; Mitchell et al., 1996; Blackburn et al., 1998]).

Furthermore, the energetics of production of steady-state "far-field" signal gradients is likely to be unfavorable for small cells. Signal concentration decreases as $r^{-1}$ as it diffuses outward, and beyond the near-field region within a few grazer body lengths (e.g., $>200 \mu \mathrm{m}$ ), even compounds that are highly concentrated inside cells have signal-to-noise ratios too low for detection. This problem is analogous to that of mate location by pheromones, considered by Dusenbery and Snell (1995). Their analysis suggested that for organisms that locate mates (or prey) by random contact, the considerable metabolic cost of signal production is not 


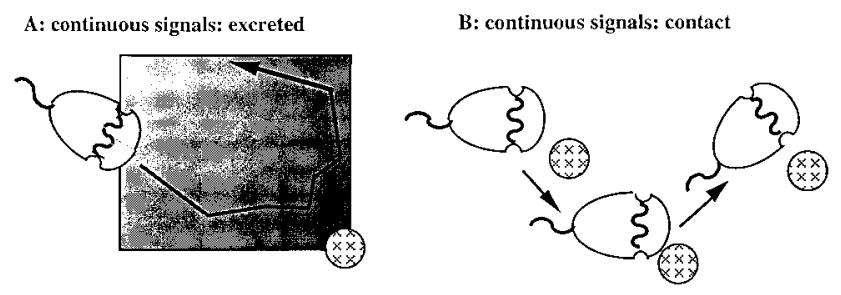

C: activated signals

i.

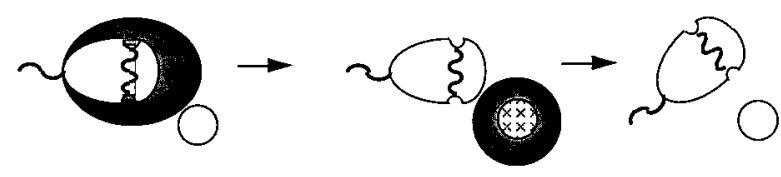

ii.

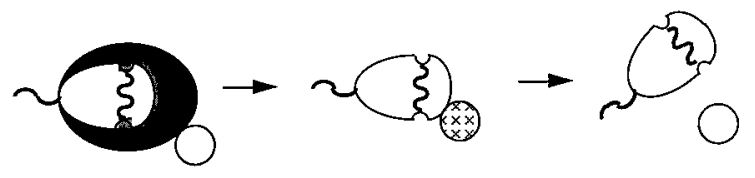

iii.
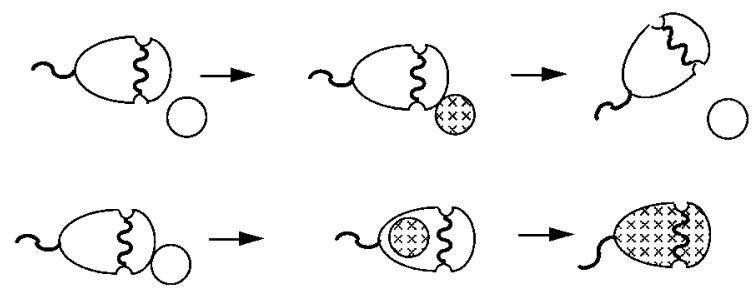

Figure 3. Hypothetical defense mechanisms. The predator is shown as a schematic dinoflagellate with longitudinal and transverse flagella; the prey is a small circle. Prey that contain defense signals or toxins are indicated by cross-hatching. (A, B) Continuous signal mechanisms. (A) Excreted signals may create a gradient around the prey that can be detected and result in avoidance via negative chemokinesis (increased frequency of turning down gradient). (B) Cell-surface signals cause release following contact. (C) Activated signals may operate briefly by several mechanisms: (i) In pulse-pulse interaction, the prey is activated by a chemical or physical signal received from the predator and responds by excretion of a signal pulse that acts as a momentary deterrent. (ii) In pulse-contact mechanism, the prey is activated by a pulsed signal eminating from the predator, but the deterrent signal occurs only after predator-prey contact. (iii) In contactcontact interaction, prey activation and signal are caused by predator-prey cell contact. (iv) In a "suicide" mechanism, activation occurs following ingestion. The latter is the only mechanism that must be toxic in order to exert a selective advantage at the prey population level.

worthwhile below a critical body size, which is probably $200 \mu \mathrm{m}$ in water, the range of most planktonic unicellular prey.

However, unsteady excretion may be a useful way to signal cells in close proximity (Fig. 3c, part i). Diffusivesignal pulse speeds scale as $6 \mathrm{Dr}^{-1}$, so pulses move at $6000-600 \mu \mathrm{m} \mathrm{s}^{-1}$ within $1-10 \mu \mathrm{m}$ of a cell for $\mathrm{D} \sim 10^{-5}$ $\mathrm{cm}^{2} \mathrm{~s}^{-1}$. Such signal fronts may precede grazer cells for very brief distances and possibly alert a prey cell, but the rapid decrease in concentration with radius makes this unlikely to be effective. Ciliary or flagellar propulsion systems typically operate at $50 \mathrm{~Hz}$ or slower; within the 20 -ms beat time, receptor integration could detect $\sim 100 \mathrm{n} M$ signal pulses, but whether such brief events could be transduced and converted to kinetic responses is unknown. One wellknown example of pulsed signaling occurs in the social amoeba Dictyostelium discoides. Aggregates of cells relay waves of cAMP to control reproductive development (Nanjundiah, 1973; Devreotes, 1982). The waves vary in concentration from 10-1000 n $M$ but occur over much longer (minute) time scales.

Contact signals. Once predator and prey come into immediate proximity, direct contact offers the next of chemical transmission (Fig. 3b, c). Contact-mediated defense systems are well-known in protozoa (Fig. 3c, ii and iii). The "avoidance reaction" in ciliates is caused by massive ciliary hyperpolarization in response to chemical or mechanical cues (Jennings, 1906). Extrusome discharge occurs during predator-prey contact (Wesenberg and Antipa, 1970; Harumoto and Miyake, 1991; Knoll et al., 1991).

More fundamentally, contact-mediated signaling mechanisms are a universal hallmark of cellular communication within multicellular organisms. Such signals are usually extensions of the cell plasma membrane, the carbohydraterich glycocalyx, which contains both glycoproteins and proteoglycans secreted into the extracellular space and adsorbed onto the cell surface. Two major classes of compounds appear to mediate most cell-contact interactions: protein-sugars and polypeptides take major roles in selfrecognition and as attractants and deterrents (Köhidai and Csaba, 1996). The rich variety of oligosaccharide structures that can be formed with a limited set of oligomers and glycosidic linkages probably contributes to their utility for protein recognition (Sharon and Lis, 1993; Lowe, 1994). Lectins, proteins that bind specific oligosaccharide groups, function universally for "self $v s$. non-self" discrimination and have been hypothesized to be precursors of vertebrate immune systems (Burnet, 1971; Popescu and Misevic, 1997). They are used universally by microbes for intraspecific chemical communication (Doyle, 1994), mediating such intraspecific activities as adhesion or settlement (Kirchman et al., 1982), cell agglutination and colony formation (Waite et al., 1995), and mating interactions (van den Ende, 1985; Delmonte Corrado et al., 1997). Their signaling role in phagocytosis is still poorly understood, but they probably contribute to predator-prey recognition in some systems (Rabinovitch and De Stefano, 1971; Brown et al., 1975; Hellio and Ryter, 1980; Vogel et al., 1980).

Peptide or polypeptide signals are the other major class of surface-active signals; both excreted and cell-surface peptides probably play major roles in signaling. Peptide signals and surface receptors occur widely in protozoa (LeRoith et al., 1982; Freiburg, 1993; Luporini et al., 1995; Ortenzi and Luporini, 1995), and many protozoa have receptors for vertebrate hormones (reviewed above). Peptide cues released to the environment act for self-recognition (Kusch, 1999) or as mating pheromones (Beale, 1990), and they may 
stimulate chemosensory responses (Leick and HellungLarsen, 1985; Köhidai et al., 1994; Kuhlmann et al., 1997) or have mitogenic activity (Vallesi et al., 1995). Little is known about peptide-mediated signaling among marine planktonic protists, but peptides probably function universally as chemocues in the marine environment (Rittschof, 1990; Decho et al., 1998).

Post-ingestion (suicide) signals. The final frontier of chemical defense signaling follows ingestion and involves inhibitory reactions or highly toxic prey molecules. Constitutive toxins, already discussed, may incapacitate grazers (Hansen, 1989; Hansen et al., 1992). Metazoan grazers may regurgitate toxic prey (Huntley et al., 1986), but expelled cells appear to be damaged and suffer lower growth rates.

From an evolutionary viewpoint, suicide signals seem to make little sense for microbes without tissue to sacrifice: selection for such mechanisms is unlikely because the prey organism does not survive to reproduce. However, there may be benefit to a population of genetically identical asexually dividing prey (genets). If the pool of grazers is small relative to prey, then inhibition of grazing by the loss of a small fraction of the prey population may increase the prey gene pool; this perspective is analogous to viewing microbial populations as extended multicellular organisms or superorganisms. The extent to which genetic diversity occurs among clonal plankton is just beginning to be known (Oppen et al., 1996). However, reducing grazing pressure via toxic suicide mechanisms may allow competitor prey to avoid grazing pressure and thus decrease the fitness of toxic prey. Rather, deterrence strategies that force a grazer to select another prey would both improve survival of individuals and remove competition.

\section{A Model Mechanism for Planktonic Deterrence}

I next present a possible dynamic chemical defense model that may be widespread among marine unicellular algae, involving the cleavage of $\beta$-dimethylsulfoniopropionate (DMSP) to dimethyl sulfide (DMS), acrylate, and a proton:

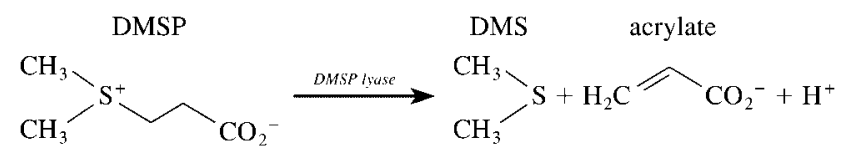

DMSP is produced by many marine algae and is especially prominent in haptophytes and dinoflagellates (Keller et al., 1989b). It is highly nontoxic and is an excellent compatible osmolyte (Dickson and Kirst, 1987). It may also serve for transmethylation reactions (Ishida and Kadota, 1968) or act as a cryoprotectant (Karsten et al., 1996). The enzyme DMSP lyase (DL) has been identified in several algae and appears to be constitutive, but activity is highly variable within algal classes or even between species or strains
(Steinke et al., 1996, 1998). The basis for this variability and the functions of this reaction are not yet known. Many details on the chemistry and biology of DMSP, DMS, and related compounds can be found in several symposia proceedings (Saltzman and Cooper, 1989; Kiene et al., 1996).

\section{DMSP cleavage: strain specificity and behavior}

The unicellular nanoplanktonic $(2-20 \mu \mathrm{m})$ haptophyte alga Emiliania huxleyi provides a hint of the variability of the DMSP lyase enzyme within a species. Axenic strains were obtained from the Bigelow-Provasoli culture collection (CCMP, Boothbay Harbor, ME) and maintained in serial batch cultures. All strains contained near-equal concentrations of DMSP, but in vitro DMSP lyase activity of sonicated cells was high in strains 373 and 379 but low in 370 and 374 (Wolfe and Steinke, 1996; Steinke et al., 1998); different $\mathrm{pH}$ and salt enzyme optima were also observed among the strains (Steinke et al., 1998).

In all strains, although DMSP lyase is a constitutive enzyme, cleavage-deduced from DMS production-does not appear to occur in healthy growing cells (Wolfe and Steinke, 1996; Fig. 4a). Rather, stresses such as cell lysis caused immediate activation of the reaction, which was hypothesized to be a result of mixing compartmented substrate and enzyme (Wolfe and Steinke, 1996). Viral lysis of the DL-containing haptophyte Phaeocystis pouchetii also initiates DMS production (Malin et al., 1998). However, complete lysis may not be necessary: merely sparging water containing Phaeocystis colonies activates DMS production (Wolfe et al., 2000). It also appears that DMSP cleavage can be stimulated in other haptophytes and dinoflagellates by mechanical stress (bubbling or shaking) or by chemical triggers that activate exocytosis, such as polyamino compounds (Wolfe, unpubl. data). Therefore, algae with high in vitro DMSP lyase activity may only potentially cleave DMSP in vivo; I term this DMSP-cleavage potential, or DCP. When high-DCP prey are grazed, DMS is produced (Fig. 4b), apparently only during or following ingestion (Fig. 4c).

\section{Selective ingestion of low-DCP prey}

Although there is considerable variation in specificity of feeding responses by heterotrophic dinoflagellates and ciliates to different strains of E. huxleyi, there is a striking correlation of feeding inhibition with prey DCP. Some grazers (Oxyrrhis marina) show subtle feeding selectivity: rather than near-total inhibition of ingestion, this taxon ingests and grows successfully on high-DCP strains (Fig. 4b) but ingests them at lower rates (Wolfe et al., 1997) or selects against them in prey mixtures (Fig. 4c, Wolfe et al., 1997). Other grazers (the dinoflagellates Amphidinium and Gymnodinium spp. and a urotrichous ciliate) are much more sensitive: they readily ingest low-DCP E. huxleyi prey 

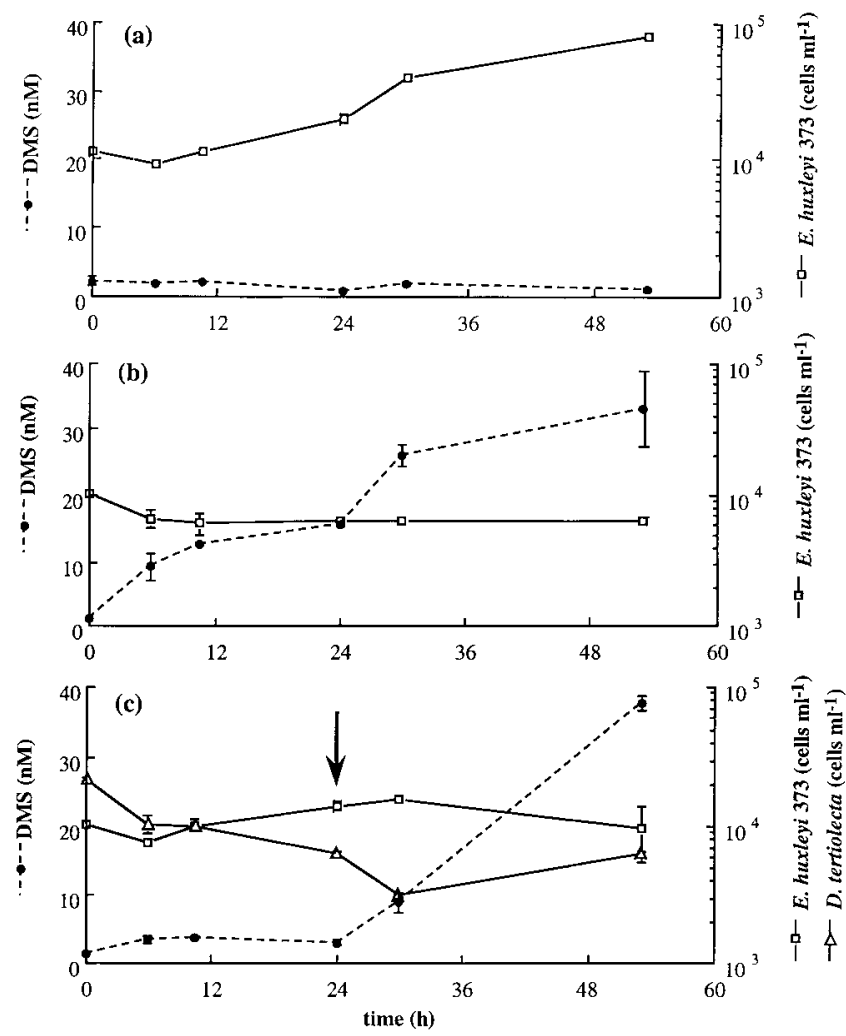

Figure 4. Example of dimethylsulfide (DMS) production during ingestion of Emiliania huxleyi with high potential for cleavage of $\beta$-dimethylsulfoniopropionate (DMSP) by the dinoflagellate Oxyrrhis marina, illustrating DMSP cleavage activated by ingestion of prey. DMS is shown as black circles and dashed lines, while prey cell numbers (on a log scale) are shown by white circles. (a) E. huxleyi alone grew exponentially and produced no DMS. (b) Addition of Oxyrrhis cropped growth and produced continuous DMS. (c) Oxyrrhis fed a food mixture containing the chlorophyte Dunaliella tertiolecta (white triangles) and E. huxleyi. 373 showed feeding selectivity, feeding on Dunaliella exclusively during the first $24 \mathrm{~h}$. Despite the presence of physical and chemical grazing cues present during this period, DMS production did not begin until Emiliania cells were ingested (arrow). Data points are means of duplicates, with ranges as error bars.

(strains 370, 374), but ingestion of high DCP strains is low or zero (Fig. 5). These grazer taxa are more representative of surface waters and probably co-occur with Emiliania, although the identities of natural grazers are not yet known.

Prey strains are morphologically similar, and gross chemical composition (total $\mathrm{C}, \mathrm{N}$, protein, lipid, carbohydrate, mineral, dry weight [S. Strom and Wolfe, unpubl. data]) suggests only minor variations among strains. Although lipid profiles and specific metabolite pools are not known and may vary among strains, prey DMSP and pigment profiles also show little variation, as do cell-surface carbohydrates (Wolfe, unpubl. data). Therefore, although there are likely to be other factors that contribute to feeding selectivity, DCP is the only clear polymorphism that cova- ries with feeding selectivity and probably plays a role in deterring various protozoan grazers.

\section{Possible deterrence mechanisms}

The mechanism for feeding deterrence by DMSP cleavage is still poorly understood. The DMSP cleavage reaction was hypothesized to be compartmented (Wolfe et al., 1997). DMSP and analogs have been found localized in the cytoplasm or vacuoles of other microorganisms (Schlenk et al., 1970) and vascular plants (Hall et al., 1978; Leigh et al., 1981; Matoh et al., 1987), and algal DLs are membranebound enzymes (de Souza et al., 1996). However, the locations of DMSP and DLs in algae are unknown.

Observations with Oxyrrhis suggested that the DMSP cleavage reaction occurs during or after ingestion, and the DMS produced during grazing can be a sensitive signal of ingestion (Wolfe and Steinke, 1996; Fig. 4b, c). This observation led to the hypothesis that, following their ingestion, prey cells containing compartmented DMSP and DL lyse, causes a mixing reaction. DMS would presumably diffuse rapidly from predators to be detected as the reaction
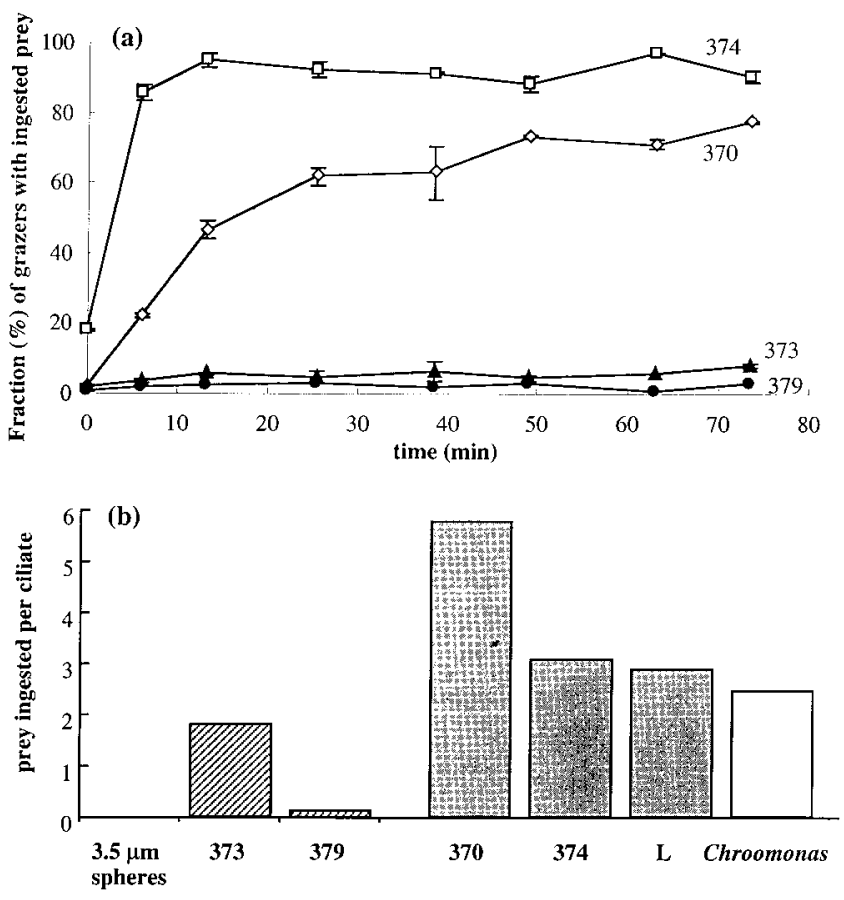

Figure 5. Example of selective ingestion of Emiliania huxleyi strains by (a) the dinoflagellate Amphidinium., showing rapid ingestion of lowDCP Emiliania strains 370 and 374 but little or no ingestion of equal titers of high-DCP strains 373 and 379. Data points are means of duplicates, with ranges as error bars. (b) Similar behavior by a urotrichous ciliate. HighDCP strains (cross-hatching) were ingested at low rates, similar to plastic spheres, while low-DCP strains (grey) were ingested at high rates, similar to preferred Chroomonas prey. Selective ingestion in both examples resulted on grazer growth or survival on low-DCP prey strains, but no growth on high-DCP strains. 

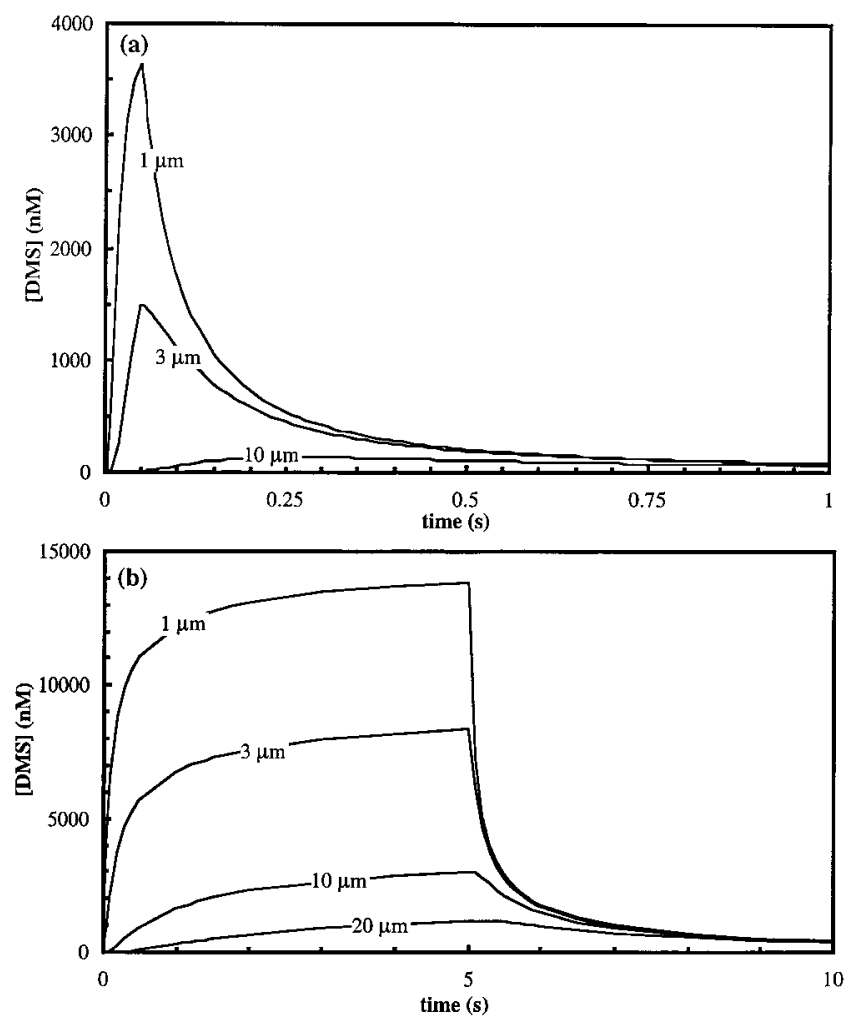

Figure 6. Model of brief $\beta$-dimethylsulfoniopropionate (DMSP) cleavage, showing a diffusive pulse of dimethylsulfide (DMS) proceeding outward from a spherical prey cell. (a) DMS concentration in the field near a $5-\mu \mathrm{m}$ prey cell following short (50-ms) cleavage reaction. Curves are denoted by distance $(\mu \mathrm{m})$ from the prey cell surface. (b) DMS concentration following a longer (5-s) cleavage reaction.

signal, but acrylic acid would be ionized above $\mathrm{pH} 4.4$ and remain internal. In support of this hypothesis, most $E$. huxleyi DLs have a mildly acidic $\mathrm{pH}$ optimum (Steinke et al., 1998) and retain significant activity even at $\mathrm{pH} 4-6$, the probable range during formation of food vacuoles. DCP rates in high-activity strains could cleave $100 \%$ of prey DMSP in a few minutes following ingestion, times typical for food vacuole formation, and thus produce concentrated acrylate inside protist food vacuoles at levels $(c a .70 \mathrm{mM})$ that have been shown to be toxic or have antimicrobial activity (Sieburth, 1960, 1961; Thijsse, 1964; Bringmann and Kühn, 1980).

Thus, the original DMSP cleavage hypothesis was an activated form of a "suicide" reaction (Fig. 3c, iv), although this mechanism now appears unlikely. Even protozoa that ingest high-DCP prey and promote the reaction show no overt toxicity. Moreover, most grazers simply do not ingest high-DCP strains of prey (Fig. 5), and bulk DMS production is not measured. Clearly, for these grazers, the deterrent signal must occur before ingestion. If the DMSP cleavage reaction were activated by an excreted or contact-mediated grazer cue, could it produce a signal that might be detected by a grazer without producing measurable bulk DMS or acrylate?

Consider a 5- $\mu \mathrm{m}$ diameter $E$. huxleyi cell containing 6.5 fmol of DMSP. This cell has a volume of $65 \mu \mathrm{m}^{3}$. If DMSP is distributed evenly throughout the cell, its concentration is $100 \mathrm{mM}$; any subcellular localization will increase this concentration even higher. High-DCP strains have in vitro DL activity approaching $10 \mathrm{fmol}$ DMSP cleavage $\mathrm{min}^{-1}$ cell $^{-1}$ (Wolfe and Steinke, 1996; Steinke et al., 1998). For this calculation I assume for simplicity a conservative in vivo activity of $4 \mathrm{fmol} \mathrm{min}^{-1}$, or $0.067 \mathrm{fmol} \mathrm{s}^{-1}$; the cell can thus cleave DMSP at a rate of about $1 \% \mathrm{~s}^{-1}$.

Suppose that a physical or chemical disturbance near the cell-possibly following contact by a predator, or in response to near-field hydrodynamic disturbance-activates the reaction briefly. The DMS generated would rapidly permeate the cell membrane; acrylic acid permeability is highly $\mathrm{pH}$-dependent: ionized acrylate would remain inside, while protonated acrylic acid would permeate the cell membrane and become ionized outside the cell.

The resulting "pulse" of DMS can be calculated by simple diffusion, approximated as a spherically symmetric point source at $r=0$. I consider two cases for pulses of different lengths. For an instantaneous pulse of duration $\mathrm{t}_{\mathrm{o}}$, the concentration pulse diffusing from the cell is given by $\mathrm{C}$ $(\mathrm{r}, \mathrm{t})=\mathrm{i} \mathrm{t}_{\mathrm{o}}(4 \pi \mathrm{Dt})^{-3 / 2} \exp \left(-\mathrm{r}^{2} / 4 \mathrm{Dt}\right)(\mathrm{Berg}, 1983)$, where $\mathrm{i}=0.067 \mathrm{fmol} \mathrm{s}^{-1}$ and $\mathrm{D} \sim 10^{-6} \mathrm{~cm}^{2} \mathrm{~s}^{-1}\left(100 \mu \mathrm{m}^{2} \mathrm{~s}^{-1}\right)$. The pulse moves outward as a wavefront whose radial velocity diminishes as $6 \mathrm{Dr}^{-1}$. The peak concentration diminishes as $\mathrm{r}^{-3}$, and the concentration gradient scales as $\mathrm{r}^{-5}$ due to rapid dissipation. An example in which $\mathrm{t}_{\mathrm{o}}=50 \mathrm{~ms}$ is shown in Figure 6a. In this time, $0.003 \mathrm{fmol}$ of algal DMSP, or $0.05 \%$, is cleaved. The pulse moves rapidly outward near the cell, reaching $1 \mu \mathrm{m}$ from the surface in 20 $\mathrm{ms}, 5 \mu \mathrm{m}$ in $94 \mathrm{~ms}$, and $10 \mu \mathrm{m}$ in $260 \mathrm{~ms}$, but taking $4.6 \mathrm{~s}$ to reach $50 \mu \mathrm{m}$. The peak concentration at $1 \mu \mathrm{m}$ is $5.7 \mu M$, which decays rapidly to only $0.13 \mu M$ at $10 \mu \mathrm{m}$.

For longer pulses, $\mathrm{C}(\mathrm{r}, \mathrm{t})=\mathrm{i}(4 \pi \mathrm{Dt})^{-1} \operatorname{erfc}\left(\mathrm{r}[4 \mathrm{Dt}]^{-1 / 2}\right)$ (Berg, 1983). Figure 6b shows the concentration field produced by a production pulse $5 \mathrm{~s}$ long. In this time, $0.33 \mathrm{fmol}$ of algal DMSP, or $5 \%$, is cleaved. Over the $5 \mathrm{~s}$ of steady production, the pulse peak builds up, but although the amount of signal released is 100-fold larger than the prior example, the peak concentration is less than 3 -fold greater, reaching $15 \mu M$ at $1 \mu \mathrm{m}$ from the cell surface. However, the integrated pulse is much longer, and the concentration decay is less, so the signal strength at longer distances is much greater: at $10 \mu \mathrm{m}$ from the cell about $5 \mathrm{~s}$ later the peak concentration is nearly 20 -fold higher than for the short pulse. When production stops, the concentrations rapidly decay.

These examples, though hypothetical, reveal some interesting strategies for near-field pulsed signals. Since grazer receptor sensitivity is likely to be in the nanomolar range, 
Table 2

Phytoplankton that have negative chemical effects on zooplankton predators

\begin{tabular}{|c|c|c|c|c|}
\hline Class & Prey genera & Predators & Effects* & References \\
\hline \multirow[t]{2}{*}{ Cyanophyceae } & Trichodesmium & Copepods & $\mathrm{AT}$ & Hawser et al., 1992 \\
\hline & Cyanobacteria spp. & $\begin{array}{l}\text { Copepods, daphnids, } \\
\text { cladocerans, rotifers }\end{array}$ & $\mathrm{AV}, \mathrm{AT}, \mathrm{FI}, \mathrm{GR}$ & $\begin{array}{l}\text { DeMott and Moxter, 1991; DeMott et al., 1991; Kirk and } \\
\text { Gilbert, 1992; Haney et al., } 1995\end{array}$ \\
\hline Bacillariophyceae & $\begin{array}{l}\text { Phaeodactylum, } \\
\text { Thalassiosira }\end{array}$ & Copepods & FI & Shaw et al., 1995 \\
\hline \multirow[t]{3}{*}{ Prymnesiophyceae } & Emiliania & Dinoflagellates, ciliates & AV & $\begin{array}{l}\text { Wolfe and Steinke, 1996; Wolfe et al., 1997; Strom and } \\
\text { Wolfe, unpublished data }\end{array}$ \\
\hline & Phaeocystis & Ciliates, copepods & AV & Admiraal et al., 1986; Estep et al., 1990; Hansen et al., 1990 \\
\hline & Chrysochromulina & Ciliates, copepods & AT, GR & Carlsson et al., 1990; Nielsen et al., 1990; Turiff et al., 1995 \\
\hline \multirow[t]{3}{*}{ Dinophyceae } & Alexandrium & Ciliates, copepods & AT, GR, AV & $\begin{array}{l}\text { Hansen, 1989; Bagøien et al., 1996; Teegarden and } \\
\quad \text { Cembella, } 1996\end{array}$ \\
\hline & Gymnodinium & Copepods & AT, GR, AV & Fiedler, 1982; Bagøien et al., 1996 \\
\hline & Dinophysis & Copepods & $\mathrm{AV}$ & Carlsson et al., 1995 \\
\hline Chrysophyceae & Olisthodiscus & Tintinnids, rotifers & AT, FI, GR & Verity and Stoecker, 1982; Egloff, 1986 \\
\hline
\end{tabular}

$* \mathrm{AT}=$ Acute Toxicity, FI $=$ Feeding Inhibition, AV $=$ Avoidance, GR $=$ Growth Reduction.

peaks at micromolar concentrations should be easily detectable. If peak concentration is key and grazers are at contact or near-contact, it makes little sense energetically to emit a pulse of $5 \mathrm{~s}$ relative to $0.05 \mathrm{~s}$; only roughly $3 \%$ of the additional potential concentration maximum is achieved. But if perception of signals requires longer integration times, or if the grazers to be signaled are at a distance of several prey body lengths, longer pulses may be useful. Such short events are difficult to measure because they have little effect on bulk DMS concentrations. Assuming $10^{4}$ prey cells $\mathrm{ml}^{-1}$, prey DMSP titers would be equivalent to 65 $\mathrm{n} M$ bulk DMSP. Even if every prey cell were activated and converted 5\% of its DMSP, the bulk DMS produced would be only $3.5 \mathrm{n} M$, barely above typical background levels of 1-3 $\mathrm{n} M$.

The behavioral responses of dinoflagellate and ciliate grazers to gradients of DMS, DMSP, and acrylate are currently being investigated. Predator swimming behavior in response to gradients of dissolved cues and specific prey strains was filmed and analyzed by computer-aided motion analysis (Sjoblad and Mitchell, 1979; Zimmer-Faust et al., 1996), and preliminary observations suggest that Amphidinium's motions are greatly inhibited by acrylate (R. Zimmer, pers. comm.). However, additions of nanomolar concentrations of DMSP, rather than acrylate or DMS, inhibit feeding (S. Strom, unpubl. data). The signal potential of these compounds is clear, but their sense is not.

\section{Ecological Implications of Plankton Defenses in Food Webs}

How might planktonic predator-prey interactions, such as chemical defense effects on feeding selectivity, affect mi- crobial food webs, trophic ecology, and biogeochemical impacts? I briefly examine several aspects.

\section{Selective feeding and trophic structure}

Many algae are toxic to, or avoided by, metazoan or protozoan grazers (Table 2). Although early studies focused on prey containing highly potent toxicants, it is likely that other strategies that affect predator feeding selectivity may be more important and widespread. Many marine protozoan grazers are known to selectively ingest or reject particular prey [Table 3, (Stoecker et al., 1986; Taniguchi and Takeda, 1988; Verity, 1991; Stoecker et al., 1995; Strom and Loukos, 1998)], and prey preferences differ among predators (Rapport et al., 1972; Hansen et al., 1996; Buskey, 1997; Strom and Loukos, 1998). Different grazer taxa and functional groups may have different selection capabilities. For example, filter feeders may select prey according to size and hydrodynamic characteristics, whereas raptorial feeders may use chemodetection to avoid contacting and capturing noxious prey. Although the feeding mechanisms of suspension (filter) feeders strongly determine the size spectrum of particles that they can capture, many also appear to discriminate between similarly sized particles with different chemical characteristics (Stoecker, 1988; Verity, 1991).

Different selective feeding mechanisms can have very different consequences for the long-term persistence of prey populations. For example, a grazer that consistently prefers a given prey type can, in the absence of a physical or behavioral refuge, ultimately eliminate that prey type from the environment. On the other hand, selection behavior that varies as prey abundance or community composition changes can stabilize predator-prey dynamics and create a 
Table 3

Examples of selective ingestion by planktonic protozoa

\begin{tabular}{|c|c|c|}
\hline Grazer & Ingestion preference* & References \\
\hline \multicolumn{3}{|l|}{ Ciliates } \\
\hline Eutintinnus pectinis & Prefers Isochrysis to Dunaliella & Heinbokel, 1978 \\
\hline Favella taraikaensis & Rejects captured Heterosigma, Rhodomonas & Taniguchi and Takeda, 1988 \\
\hline \multirow[t]{3}{*}{ Favella sp. } & Prefers dinoflagellates to other algae & Stoecker et al., 1981 \\
\hline & Prefers live $v s$. dead cells & Stoecker, 1988 \\
\hline & Prefers inert microspheres to dead cells & \\
\hline \multirow[t]{2}{*}{ Balanion sp. } & Prefers dinoflagellates to other algae & Stoecker et al., 1986 \\
\hline & Prefers dinoflagellates to latex microspheres & \\
\hline Strombilidium spiralis & Prefers Isochrysis to Cafeteria & Verity, 1991 \\
\hline Tintinnopsis & Prefers Paraphysomonas to Dunaliella & Verity, 1991 \\
\hline \multicolumn{3}{|l|}{ Flagellates } \\
\hline Gymnodinium fungiforme & Prefers specific strains of Dunaliella & Spero and Morée, 1981 \\
\hline \multirow[t]{2}{*}{ Oxyrrhis marina } & Prefers Dunaliella to beads & Tarran, 1991 \\
\hline & Avoids high-DCP E. huxleyi strains (in mixtures) & Wolfe et al., 1997 \\
\hline Amphidinium sp. & Avoids high-DCP E. huxleyi strains & Strom and Wolfe, unpublished data \\
\hline Protoperidinium sp. & Prefers diatoms & Jacobsen and Anderson, 1986 \\
\hline
\end{tabular}

$*$ DCP $=$ DMSP Cleavage Potential.

refuge for prey populations (Strom and Loukos, 1998). The degree of feeding specialization or generality is poorly known for planktonic protists, as are even the natural codistributions of predator and prey taxa. Recent evidence on bacterivore grazers suggests that predation can cause major shifts in food abundance and taxa (Hahn and Höfle, 1998; Jürgens et al., 1999). Such "top-down" control probably extends to other members of the microbial food web, but the degree to which chemical cues play a role in such selection is not yet known.

\section{Competition: algal blooms}

Bloom-forming algal taxa increasingly are being studied because of their potential to disrupt marine food-chains and cause toxicity to humans (harmful algal blooms, HABs [Hallegraeff, 1995]). Evidence suggests that HABs are increasing in coastal environments as a result of nutrification. Most blooms are seasonal, but in the past decade there have been novel reports of essentially indefinite blooms. Coastal Texas has experienced a "brown tide" of the chrysophyte Aureococcus for over five years, while an E. huxleyi bloom in the Bering Sea has persisted for two years (Vance et al., 1998); both blooms have had dramatic impacts on regional food webs.

The role of antipredator defenses or toxins in establishing and maintaining such blooms is poorly understood (Turner and Tester, 1997; Turner et al., 1998) but probably contributes to their success (Buskey and Hyatt, 1995; Buskey et al., 1997). A decade ago, Keller et al., (1989a) observed that many bloom-forming algal taxa form considerable DMSP and suggested the likelihood that blooms contribute to global DMS emissions. Many taxa from the Haptophyceae and Dinophyceae, two dominant bloom-forming groups, not only produce concentrated DMSP but seem to have high DL activity (Table 4); several appear to operate as activated systems. Phaeocystis pouchetii, a bloom-forming haptophyte closely related to Emiliania, has a colonial life stage that forms large (1-mm) colonies concentrated in spherical shells of polysaccharide mucus (van Rijssel et al., 1997) that are critical to its widespread ecological success (Lancelot and Rosseau, 1994). P. pouchetii appears to have a

Table 4

$\beta$-dimethylsulfoniopropionate (DMSP) and DMSP lyase (DL) activity in bloom-forming marine phytoplankton (blank $=$ not determined $)$

\begin{tabular}{|c|c|c|c|c|}
\hline Class/taxa & Strain & $\begin{array}{c}\mathrm{m} M \\
\text { DMSP }\end{array}$ & $\mathrm{DL}^{1}$ & Mode $^{2}$ \\
\hline \multicolumn{5}{|l|}{ Prymnesiophyceae } \\
\hline $\begin{array}{l}\text { Chrysochromulina } \\
\text { polylepis }\end{array}$ & ED1/ED2 & $192-395$ & & \\
\hline Prymnesium parvum & CCMP 708 & $179-223$ & $<0.02$ & LA? \\
\hline Phaeocystis pouchetii & $677-3$ & 260 & 3.1 & EX \\
\hline Phaeocystis sp. & Labrador sea & & & LA? \\
\hline Emiliania huxleyi & Various & $75-110$ & $0.01-12.6$ & LA \\
\hline \multicolumn{5}{|l|}{ Dinophyceae } \\
\hline Alexandrium tamarense & CCMP 115 & $282-292$ & $17.0-23.2$ & LA \\
\hline A. tamarense & CCMP 118 & 460 & 36.5 & LA \\
\hline A. fundyense & CCMP 1719 & 640 & 30.5 & LA \\
\hline Amphidinium carterae & AMPHI & 2202 & & \\
\hline Gonyaulax spinifera & GP60e & 145 & & \\
\hline Gymnodinium breve & CCMP 718 & 109 & $<0.01$ & \\
\hline
\end{tabular}

${ }^{1}$ In vitro activity: fmol DMS cell ${ }^{-1} \mathrm{~min}^{-1} @ 10-20 \mathrm{~m} M \mathrm{DMSP}, 30^{\circ} \mathrm{C}$, $\mathrm{pH}$ 6.0.

${ }^{2}$ DMSP lyase mode of action: LA $=$ lysis-activated; EX $=$ extracellular. 
cell-surface DL (Stefels and van Boekel, 1993) and may pump DMSP across the cell membrane and cleave it externally, where the acrylate produced becomes highly concentrated at the colony surface (Noordkamp et al., 1998). This may help deter mesozooplankton grazers, although grazing on this taxon is highly variable (Weisse et al., 1994). Measurements of in situ DL activity and of grazing rates on algal populations (Stefels et al., 1995) will be necessary to assess the deterrent role of this reaction in bloom formation and maintenance.

\section{Populations and evolution}

Andrews (1991), in a pioneering attempt to forge unifying themes, has compiled an excellent comparison of ecological concepts between micro- and macroorganisms. However, little has been done to apply models of organismal behavior and ecology from the macroscopic world to understanding interactions among microbes, through concepts such as coevolution of predator and prey (Bernays, 1998; Lima, 1998), functional defense groups or defense guilds (Atsatt and O'Dowd, 1976), and complex multitrophic interactions (De Moraes et al., 1998). And yet, just as multicellular organisms and their sensory systems derived ultimately from microbial ancestors, the organismal interactions of the macroscopic world also probably reflect earlier models developed in microbial populations, modified by changes in physical scaling and developmental complexity.

Just as microbial sensory systems most likely evolved into those of multicellular organisms (Carlile, 1975; Anderson, 1989; Carr, 1989), conserved microbial behaviors and organismal interactions may be the basis of those we know so well from "higher" animals and plants. However, applying macroscopic world ecological concepts to microbes requires caution. Many standard concepts in macroscale ecology simply break down in the microbial realm, and one reason the protists are so poorly studied is that they do not fall neatly into standard biological divisions. For example, metabolic and nutritional modes are astonishingly diverse and fluid; it is estimated that a large fraction of photoautotrophic plankton can simultaneously use heterotrophic nutrition (mixotrophy), either by uptake of dissolved organic solutes or by ingestion of organic particles (Boraas et al., 1988; Stoecker, 1992). This capability blurs delineation of primary and secondary producers, or herbivores and carnivores. Trophic interrelations and levels are fluid and difficult to distinguish (Pomeroy, 1992), and terms like "grazer" and "predator" are used interchangeably. Community-level patterns such as succession, niche occupation, and coevolution are only crudely known, and even the species concept is poorly defined for microbes that divide both sexually and asexually (Manhart and McCourt, 1992; Wood and Leatham, 1992; Colwell et al., 1995) and where horizontal gene transfer appears rapid and rampant (Dahlberg et al., 1998). Even where the concepts have meaning, they are poorly constrained by current data on natural populations. For example, genetic variation is just beginning to be known within phytoplankton classes or species (Costas et al., 1995; Medlin et al., 1996; Larsen and Medlin, 1997; Scholin, 1998), much less within natural populations (Brand, 1989) or blooms (Gallagher, 1998) - and even less is known of marine protozoa (Lim et al., 1996).

\section{Microbial signals as kairomones}

Signals emitted to the environment are likely to be intercepted and used by receivers other than those intended; such cues benefit the receiver and are termed kairomones. Well known from plant-insect studies, byproducts of microbial deterrence are just beginning to be discovered. A beautiful example is the peptide "A-factor" excreted by Amoeba proteus, which inhibits phagocytosis and is used for self recognition to avoid cannibalism (Kusch, 1999). Exposure to this peptide induces the potential prey ciliate Euplotes to produce armored "wings" or "helmets" that make it too large to be ingested by Amoeba (Wicklow, 1997). It is likely that a complex of multitrophic chemical interactions, similar to that emerging from better-known terrestrial systems, also occurs in marine plankton.

The DMSP-DMS-acrylate system and close chemical analogs show widespread chemical signal activity and have the potential to act as kairomones at many spatial scales. DMSP is a sensitive chemoattractant for the heterotrophic dinoflagellate Crypthecodinium cohnii (Hauser et al., 1975b), which feeds on the surfaces of decaying macroalgae. DMSP is also a close chemical analog of quaternary or tertiary amines known to act as alarm cues in metazoans, including anthopleurine (Howe and Sheikh, 1975) and homarine (McClintock et al., 1994). Such compounds may stimulate cholinergic receptors (Mackie and Grant, 1974), possibly giving them broad activity to vertebrates and invertebrates. Trimethylamine, a volatile nitrogen analog of DMS produced microbially as a decay byproduct, appears to initiate vertical migration in freshwater daphnids (Boriss et al., 1999) as a defense against predatory fish (Nesbitt $e$ t al., 1996). Micromolar levels of DMS and acrylate may act as attractants for marine bacteria (Sjoblad and Mitchell, 1979; Zimmer-Faust et al., 1996). Many volatile fatty acids also probably function as signals; they have the useful properties of being soluble in both water and lipid, volatile, and rapidly degraded. Formic acid, a close analog of acrylic acid, is a well-known alarm and defense signal in the formacine ants from which it was first isolated (Löfqvist, 1976). Finally, DMS produced from DMSP sequestered at higher trophic levels may act as a chemoattractant for vertebrates such as procellariiform seabirds (Nevitt et al., 1995; Nevitt, 1998, 2000), helping them to locate food patches. 


\section{Conclusions and Research Challenges}

I have tried to synthesize information about the physical constraints and physiological adaptations to chemical signaling between microbes in environments characterized by low Reynolds numbers. Several general themes emerge to suggest the importance of short-range or contact mechanisms acting over very short time scales; activated reactions; multifunctional defense systems or components; and the multiple interpretations of chemical signals by many different receivers.

The behavioral, temporal, and spatial scales of unicellular microbes are small, difficult to determine experimentally, and unfamiliar to human experience. Clearly, the technical challenges of measuring "what the cell sees" are vast. We have just begun to measure the microscale structure and perception of fluid flow around millimeter-sized grazers (Moore et al., 1999, and other papers in this volume), much less around protozoans 50- to 100-fold smaller. Even the static microscale distributions of microbial populations are only beginning to be visualized (Müller-Niklas et al., 1996; Krembs et al., 1998); their chemical interactions are a still greater challenge. From a chemical perspective, ecologists need to consider not only the constituents of microbes that may act as deterrents or signals, but also reactions that are activated in response to subtle cues and do not occur in ungrazed prey.

Chemical ecology in environmentally important planktonic microbial populations is in its infancy. This state is not surprising given the recency of information on the basic diversity, structure, and stability of marine microbial populations (Allsopp et al., 1995); moreover, the application of macroecological concepts to microbial ecology has barely begun (Andrews, 1991). Nonetheless, chemically mediated, behavioral microbial interactions are probably important and may result in large-scale changes in trophic structure and function. Synthesis of work at the chemical, genetic, physiological, behavioral, and population levels will also be necessary to understand microbial chemical communication and its impact in the environment, but it is easy to predict that a rich world of microbial chemical communication, both adversarial and mutualistic, awaits researchers who venture into this difficult realm.

\section{Acknowledgments}

I thank Dick Zimmer for inviting me to participate in this symposium and for stimulating interdisciplinary discussion of chemical ecology. Michael Steinke and Suzanne Strom conducted many of the DMSP-cleavage and grazing experiments, shared unpublished data, and were key contributors to the ideas presented. Peter Jumars, Dick Zimmer, and an anonymous reviewer provided critical comments and suggested many improvements. This work was supported by grants from NASA (NAGW-3737) and NSF (OCE-975051).

\section{Literature Cited}

Aaronson, S. 1981. Chemical Communication at the Microbial Level. CRC Press, Boca Raton, FL.

Abrahams, M. V., and L. D. Townsend. 1993. Bioluminescence in dinoflagellates: a test of the burglar alarm hypothesis. Ecology 74: $258-260$.

Admiraal, W., and L. A. H. Venekamp. 1986. Significance of tintinnid grazing during blooms of Phaeocystis pouchetii (Haptophyceae) in Dutch coastal waters. Neth. J. Sea. Res. 20: 61-66.

Alldredge, A., and Y. Cohen. 1987. Can microscale chemical patches persist in the sea? Microelectrode study of marine snow, fecal pellets. Science 235: 689-671.

Allsopp, D., R. R. Colwell, and D. L. Hawksworth, eds. 1995. Microbial Diversity and Ecosystem Function. CAB International, Wallingford, UK.

Almers, W. 1990. Exocytosis. Annu. Rev. Physiol. 52: 607-624.

Anderson, D. M., and T. P.-O. Cheng. 1988. Intercellular localization of saxitoxins in the dinoflagellate Gonyaulax tamarensis. J. Phycol. 24: 17-22.

Anderson, D. M., D. M. Nosenchuck, G. T. Reynolds, and A. J. Walton. 1988. Mechanical stimulation of bioluminescence in the dinoflagellate Gonyaulax polyedra Stein. J. Exp. Mar. Biol. Ecol. 122: 277-288.

Anderson, P. A. V., ed. 1989. Evolution of the First Nervous Systems. Plenum Press, New York.

Andrews, J. H. 1991. Comparative Ecology of Microorganisms and Macroorganisms. Springer-Verlag, New York.

Atsatt, P. R., and D. J. O'Dowd. 1976. Plant defense guilds. Science 193: $24-29$.

Bagøien, E., A. Miranda, B. Reguera, and J. M. Franco. 1996. Effects of two paralytic shellfish toxin producing dinoflagellates on the pelagic harpacticoid copepod Euterpina acutifrons. Mar. Biol. 126: 361-369.

Barns, S. M., and S. Nierzwicki-Bauer. 1997. Microbial diversity in modern subsurface, ocean, and surface environments. Pp. 35-80 in Geomicrobiology: Interactions Between Microbes and Minerals, J. F. Banfield and K. H. Nealson, eds. Mineralogical Society of America, Washington, DC.

Beale, G. 1990. Self and nonself recognition in the ciliate protozoan Euplotes. Trends Genet. 6: 137-139.

Bell, W., and R. Mitchell. 1972. Chemotactic and growth responses of marine bacteria to algal extracellular products. Biol. Bull. 143: 265277.

Bennett, S. J., R. W. Sanders, and K. G. Porter. 1988. Chemosensory responses of heterotrophic and mixotrophic flagellates to potential food sources. Bull. Mar. Sci. 43: 764-771.

Berg, H. C. 1983. Random Walks in Biology. Princeton University Press, Princeton.

Berg, H. C., and E. M. Purcell. 1977. Physics of chemoreception. Biophys. J. 20: 193-219.

Bernays, E. A. 1998. Evolution of feeding behavior in insect herbivores. Bioscience 48: 35-44.

Bjørnson, P. K. 1988. Phytoplankton exudation of organic matter: why do healthy cells do it? Limnol. Oceanogr. 33: 151-154.

Blackburn, N., T. Fenchel, and J. Mitchell. 1998. Microscale nutrient patches in planktonic habitats shown by chemotactic bacteria. Science 282: $2254-2256$.

Boraas, M. E., K. W. Estep, P. W. Johnson, and J. M. Sieburth. 1988. Phagotrophic phototrophs: the ecological significance of mixotrophy. $J$ Protozool. 35: 249-252.

Boriss, H., M. Boersma, and K. H. Wiltshire. 1999. Trimethylamine induces migration of waterfleas. Nature 398: 382. 
Bouck, G. B., and B. M. Sweeney. 1966. The fine structure and ontogency of trichocysts in marine dinoflagellates. Protoplasma 61: 205223.

Bowen, J. D., K. D. Stolzenbach, and S. W. Chisholm. 1993. Simulating bacterial clustering around phytoplankton cells in a turbulent ocean. Limnol. Oceanogr. 38: 36-52.

Brand, L. E. 1989. Review of genetic variation in marine phytoplankton species and the ecological implications. Biol. Oceanogr. 6: 397-409.

Bringmann, G., and R. Kühn. 1980. Comparision of the toxicity thresholds of water pollutants to bacteria, algae, and protozoa in the cell multiplication inhibition test. Water Res. 14: 231-241.

Brown, R. C., H. Bass, and J. P. Coombs. 1975. Carbohydrate binding proteins involved in phagocytosis by Acanthamoeba. Nature 254: 434-435.

Burgoyne, R. D., and A. Morgan. 1993. Regulated exocytosis. Biochem. J. 293: 305-316.

Burnet, F. M. 1971. "Self-recognition" in colonial marine forms and flowering plants in relation to the evolution of immunity. Nature 232: $230-235$.

Buskey, E. J. 1997. Behavioral components of feeding selectivity of the heterotrophic dinoflagellate Protoperidinium pellucidum. Mar. Ecol. Prog. Ser. 153: 77-89.

Buskey, E. J., and C. J. Hyatt. 1995. Effects of the Texas (USA) 'brown tide' alga on planktonic grazers. Mar. Ecol. Prog. Ser. 126: 285-292.

Buskey, E. J., and D. K. Stoecker. 1988. Locomotory patterns of the planktonic ciliate Favella sp.: adaptations for remaining within food patches. Bull. Mar. Sci. 43: 783-796.

Buskey, E. J., and E. Swift. 1985. Behavioral responses to oceanic zooplankton to simulated bioluminescence. Biol. Bull. 168: 263-275.

Buskey, E. J., P. A. Montagna, A. F. Amos, and T. E. Whitledge. 1997. Disruption of grazer populations as a contributing factor to the initiation of the Texas brown tide algal bloom. Limnol. Oceanogr. 42: $1215-1222$.

Calleja, G. B. 1984. Microbial Aggregation. CRC Press, Boca Raton, FL.

Carlile, M. J., ed. 1975. Primitive Sensory and Communication Systems Academic Press, London.

Carlsson, P., E. Granéli, and P. Olsson. 1990. Grazer elimination through poisoning: one of the mechanisms behind Chrysochromulina polyepis blooms? Pp. 116-122 in Toxic Marine Phytoplankton, E. Granéli, B. Sundström, L. Edler, and D. M. Anderson, eds. Elsevier, New York.

Carlsson, P., E. Granéli, G. Finenko, and S. Y. Maestrini. 1995. Copepod grazing on a phytoplankton community containing the toxic dinoflagellate Dinophysis acuminata. J. Plankton Res. 17: 1925-1938.

Carr, W. E. S. 1988. The molecular nature of chemical stimuli in the aquatic environment. Pp. 3-28 in Sensory Biology of Aquatic Animals, J. Atema and R. R. Fay, eds. Springer-Verlag, New York.

Carr, W. E. S. 1989. Chemical signaling systems in lower organisms: a prelude to the evolution of chemical communication in the nervous system. Pp. 81-94 in Evolution of the First Nervous Systems, P. A. V. Anderson, ed. Plenum Press, New York.

Cembella, A. D. 1998. Ecophysiology and metabolism of paralytic shellfish toxins in marine microalgae. Pp. 383-403 in NATO Advanced Workshop on the Physiological Ecology of Harmful Algal Blooms, D. M. Anderson, A. M. Cembella, and G. Hallegraef, eds. Springer, Berlin.

Chiu, D. T., C. F. Wilson, F. Ryttsen, A. Stromberg, C. Farre, et al. 1999. Chemical transformations in individual ultrasmall biomimetic containers. Science 283: 1892-1895.

Clark, K. D., T. M. Hennessey, and D. L. Nelson. 1993. External GTP alters the motility and elicits an oscillating membrane depolarization in Paramecium tetraurelia. Proc. Natl. Acad. Sci. USA 90: 3782-3786.
Colwell, R. R., R. A. Clayton, B. A. Ortiz-Conde, D. Jacobs, and E. Russek-Cohen. 1995. The microbial species concept and biodiversity. Pp. 3-15 in Microbial Diversity and Ecosystem Function, D Allsopp, R. R. Colwell, and D. L. Hawksworth, eds. CAB International, Wallingford, UK.

Costas, E., R. Zardoya, J. Bautista, A. Garrido, C. Rojo, and V. López-Rodas. 1995. Morphospecies vs. genospecies in toxic marine dinoflagellates: an analysis of Gymnodinium catenatum/Gyrodinium impudicum and Alexandrium minutum/A. lusitanicum using antibodies, lectins, and gene sequences. J. Phycol. 31: 801-807.

Cowles, T. J., R. J. Olson, and S. W. Chisholm. 1988. Food selection by copepods: discrimination on the basis of food quality. Mar. Biol. 100: $41-49$.

Crenshaw, H. C. 1992. Orientation by helical motion. III. Microorganisms can orient to stimuli by changing the direction of their rotationa motion. Bull. Math. Biol. 55: 231-255.

Csaba, G. 1996. Evolutionary significance of the hormone recognition capacity in unicellular organisms. Development of hormone receptors. Pp. 1-28 in Signaling Mechanisms in Protozoa and Invertebrates, G. Csaba and W. E. G. Müller, eds. Springer, Berlin.

Csaba, G., and W. E. G. Müller, eds. 1996. Signaling Mechanisms in Protozoa and Invertebrates. Springer, Berlin.

Dahlberg, C., M. Bergström and M. Hermansson. 1998. In situ detection of high levels of horizontal plasmid transfer in marine bacteria communities. Appl. Environ. Microbiol. 64: 2670-2675.

Dakshini, I., and K. M. M. Dakshini. 1994. Algal allelopathy. Bot. Rev. 60: 182-197.

De Moraes, C. M., W. J. Lewis, P. W. Paré, H. T. Alborn, and J. H. Tumlinson. 1998. Herbivore-infested plants selectively attract parasitoids. Nature 393: 570-573.

de Souza, M. P., Y. P. Chen, and D. C. Yoch. 1996. Dimethylsulfoniopropionate lyase from the macroalga Ulva curvata: purification and characterization of the enzyme. Planta 199: 433-438.

Decho, A. W., K. A. Browne, and R. K. Zimmer-Faust. 1998. Chemical cues: why basic peptides are signal molecules in marine environments. Limnol. Oceanogr. 43: 1410-1417.

Delmonte Corrado, M. U., D. Locatelli, L. Paleari, and G. Bottiroli. 1997. Lectin-binding sites involved in Paramecium primaurelia mating pair formation. J. Eukaryot. Microbiol. 44: 603-608.

DeMott, W. R. 1986. The role of taste in food selection by freshwater zooplankton. Oecologia 69: 334-340.

DeMott, W. R., and F. Moxter. 1991. Foraging on cyanobacteria by copepods: responses to chemical defenses and resource abundance. Ecology 72: 1820-1834.

DeMott, W. R., Q.-X. Zhang, and W. W. Carmichael. 1991. Effects of toxic cyanobacteria and purified toxins on the survival and feeding of a copepod and three species of Daphnia. Limnol. Oceanogr. 36: 13461357.

Devreotes, P. 1989. Dictyostelium discoideum: a model system for cellcell interactions in development. Science 245: 1054-1058.

Devreotes, P. N. 1982. Chemotaxis. Pp. 117-168 in The Development of Dictyostelium discoideum. Academic Press, New York.

Dickson, D. M. J., and G. O. Kirst. 1987. Osmotic adjustment in marine eukaryotic algae: the role of inorganic ions, quaternary ammonium, tertiary sulfonium and carbohydrate solutes. New Phytol. 106: 645655

Dodge, J. D., and C. Greuet. 1987. Dinoflagellate ultrastructure and complex organelles. Pp. 92-142 in The Biology of Dinoflagellates, F. J. R. Taylor, ed. Blackwell Scientific, Oxford.

Doyle, R. J. 1994. Introduction to lectins and their interactions with microorganisms. Pp. 1-65 in Lectin-Microorganism Interactions, R. J. Doyle and M. Slifkin, eds. Marcel Dekker, New York.

Dusenbery, D. B. 1992. Sensory Ecology. W. H. Freeman, New York. Dusenbery, D. B. 1998. Spatial sensing of stimulus gradients can be 
superior to temporal sensing for free-swimming bacteria. Biophys. $J$ 74: 2272-2277.

Dusenbery, D. B., and T. W. Snell. 1995. A critical body size for use of pheromones in mate location. J. Chem. Ecol. 21: 427-438.

Egloff, D. A. 1986. Effects of Olisthodiscus luteus on the feeding and reproduction of the marine rotifer Synachaeta cecilia. J. Plankton Res. 8: $263-274$.

Esaias, W. E., and H. C. Curl, Jr. 1972. Effect of dinoflagellate bioluminescence on copepod ingestion rates. Limnol. Oceanogr. 17: 901-907.

Estep, K. W., J. C. Nejstgaard, H. R. Skjoldal, and F. Rey. 1990. Predation by copepods upon natural populations of Phaeocystis pouchetii as a function of the physiological state of the prey. Mar. Ecol. Prog. Ser. 67: 235-249.

Falkowski, P. G., and J. A. Raven. 1997. Aquatic Photosynthesis Blackwell Scientific, Malden, MA.

Febvre-Chavalier, C., A. Bilbaut, J. Febvre, and Q. Bone. 1989. Membrane excitability and motile responses to the protozoa, with particular attention to the heliozoan Actinocoryne contractilis. Pp. 237-253 in Evolution of the First Nervous Systems, P. A. V. Anderson, ed. Plenum Press, New York.

Fenchel, T. 1980. Relation between particle size selection and clearance in suspension-feeding ciliates. Limnol. Oceanogr. 25: 733-738.

Fenchel, T. 1987. Ecology of Protozoa: the Biology of Free-living Phagotrophic Protists. Science Tech, Madison, WI.

Fenchel, T., G. M. King, and T. H. Blackburn. 1998. Bacterial Biogeochemistry: the Ecophysiology of Mineral Cycling. Academic Press, San Diego.

Fessenden, L., and T. J. Cowles. 1994. Copepod predation on phagotrophic ciliates in Oregon coastal waters. Mar. Ecol. Prog. Ser. 107: 103-111.

Fiedler, P. C. 1982. Zooplankton avoidance and reduced grazing responses to Gymnodinium splendens (Dinophyceae). Limnol. Oceanogr. 27: $961-965$

Field, C. B., M. J. Behrenfeld, J. T. Randerson, and P. Falkowski. 1998. Primary production of the biosphere: integrating terrestrial and oceanic components. Science 281: 237-240.

Fowden, L., and P. J. Lea. 1979. Mechanism of plant avoidance of autotoxicity by secondary metabolites, especially by nonprotein amino acids. Pp. 135-160 in Herbivores: Their Interaction with Secondary Plant Metabolites, G. A. Rosenthal and D. H. Janzen, eds. Academic Press, New York.

Freiburg, M. 1993. Identification of cell surface polypeptides of the hypotrich Euplotes octocarinatus. Archiv Protistenkunde 143: 311318.

Gall, J. G., ed. 1986. The Molecular Biology of Ciliated Protozoa Academic Press, Orlando, FL.

Gallagher, J. C. 1998. Genetic variation in harmful algal bloom species: an evolutionary ecology approach. Pp. 225-242 in NATO Advanced Workshop on the Physiological Ecology of Harmful Algal Blooms, D. M. Anderson, A. M. Cembella, and G. Hallegraef, eds. Springer, Berlin.

Gerritsen, J., and J. R. Strickler. 1977. Encounter probabilities and community structure in zooplankton: a mathematical model. J. Fish. Res. Board Can. 34: 73-82.

Gomperts, B. D., I. Hide, J. P. Bennett, A. Pizzey, and P. E. R. Tatham. 1994. The exocytotic reaction of permeabilized mast cells. Pp. 217231 in Toxins and Exocytosis, D. Suput and R. Zorec, eds. New York Academy of Sciences, New York

Görtz, H.-D., ed. 1988. Paramecium. Springer-Verlag, Berlin.

Gross, M. 1998. Life on the Edge. Plenum Trade, New York.

Haacke-Bell, B., R. Hohenberger-Bregger, and H. Plattner. 1990. Trichocysts of Paramecium: secretory organelles in search of their function. Eur. J. Protistol. 25: 289-305.
Hahn, M. W., and M. G. Höfle. 1998. Grazing pressure by a bacterivorous flagellate reverses the relative abundance of Comamonas acidovorans PX54 and Vibrio strain CB5 in chemostat cocultures. Appl. Environ. Microbiol. 64: 1910-1918.

Hall, J. L., D. M. R. Harvey, and T. J. Flowers. 1978. Evidence for the cytoplasmic localization of betaine in leaf cells of Suaeda maritima Planta 140: 59-62.

Hall, S., and G. Strichartz, eds. 1990. Marine Toxins: Origin, Structure, and Molecular Pharmacology. American Chemical Society, Washington, DC.

Hall, S., G. Strichartz, E. Moczydlowski, A. Ravindran, and P. B. Reichardt. 1990. The saxitoxins: sources, chemistry, and pharmacology. Pp. 29-65 in Marine Toxins: Origin, Structure, and Molecular Pharmacology, S. Hall and G. Strichartz, eds. American Chemical Society, Washington, DC.

Hallegraeff, G. M. 1995. Harmful algal blooms: a global overview. Pp. 1-22 in Manual on Harmful Marine Microalgae, G. M. Hallegraeff, D. M. Anderson, A. D. Cembella, and H. O. Enevoldsen, eds. UNESCO, Paris.

Haney, J. F., J. J. Sasner, and M. Ikawa. 1995. Effects of products released by Aphanizomenon flos-aquae and purified saxitoxin on the movements of Daphnia carinata feeding appendages. Limnol. Oceanogr. 40: 263-272.

Hansen, B., K. S. Tande, and U. C. Berggreen. 1990. On the trophic fate of Phaeocystis pouchetii (Hariot): III. Functional responses in grazing demonstrated on juvenile stages of Calanus finmarchicus (Copepoda) fed diatoms and Phaeocystis. J. Plankton Res. 12: 11731187

Hansen, F. C., H. J. White, and J. Passarge. 1996. Grazing in the heterotrophic dinoflagellate Oxyrrhis marina: size selectivity and preference for calcified Emiliania huxleyi cells. Aquat. Microb. Ecol. 10: 307-313.

Hansen, P. J. 1989. The red tide dinoflagellate Alexandrium tamarense: effects on behaviour and growth of a tintinnid ciliate. Mar. Ecol. Prog. Ser. 53: 105-116.

Hansen, P. J. 1995. Growth and grazing response of a ciliate feeding on the red tide dinoflagellate Gyrodinium aureolum in monoculture and in mixture with a non-toxic alga. Mar. Ecol. Prog. Ser. 121: 65-72.

Hansen, P. J., A. D. Cembella, and O. Moestrup. 1992. The marine dinoflagellate Alexandrium ostenfeldii: paralytic shellfish toxin concentration, composition, and toxicity to a tintinnid ciliate. J. Phycol. 28 : 597-603.

Harumoto, T. 1994. The role of trichocyst discharge and backward swimming in escaping behavior of Paramecium from Dileptus margaritifer. J. Eukaryot. Microbiol. 41: 560-564.

Harumoto, T., and A. Miyake. 1991. Defensive function of trichocysts in Paramecium. J. Exp. Zool. 260: 84-92.

Hauser, D. C. R., M. Levandowsky, and J. M. Glassgold. 1975a. Ultrasensitive chemosensory responses by a protozoan to epinephrine and other neurochemicals. Science 190: 285-286.

Hauser, D. C. R., M. Levandowsky, S. H. Hunter, L. Chunosoff, and J. S. Hollwitz. 1975b. Chemosensory responses by the heterotrophic marine dinoflagellate Crypthecodinium cohnii. Microb. Ecol. 1: $246-$ 254.

Hawser, S. P., J. M. O'Neill, M. R. Roman, and G. A. Codd. 1992. Toxicity of blooms of the cyanobacterium Trichodesmium to zooplankton. J. Appl. Phycol. 4: 79-86.

Hefetz, A., and M. S. Blum. 1978. Biosynthesis and accumulation of formic acid in the poison gland of the carpenter ant Camponotus pennsylvanicus. Science 201: 454-455.

Heinbokel, J. F. 1978. Studies on the functional role of tintinnids in the southern California bight. I. Grazing and growth rates in laboratory cultures. Mar. Biol. 47: 177-189.

Hellio, R., and A. Ryter. 1980. Relationships between anionic sites and 
lectin receptors in the plasma membrane of Dictyostelium discoideum and their role during phagocytosis. J. Cell Sci. 41: 89-104.

Hennessey, T. M. 1989. Ion currents of Paramecium: effects of mutations and drugs. Pp. 215-234 in Evolution of the First Nervous Systems, P. A. V. Anderson, ed. Plenum Press, New York.

Howe, N. R., and Y. M. Sheikh. 1975. Anthopleurine: a sea anemone alarm pheromone. Science 189: 386-388.

Huntley, M., P. Sykes, S. Rohan, and V. Marin. 1986. Chemicallymediated rejection of dinoflagellate prey by the copepods Calanus pacificus and Paracalanus parvus: mechanism, occurrence and significance. Mar. Ecol. Prog. Ser. 28: 105-120.

Ishida, Y., and H. Kadota. 1968. Participation of dimethyl- $\beta$-propiothetin in transmethylation reaction in Gyrodinium cohnii. Bull. Jpn. Soc. Sci. Fish. 34: 699-705.

Jackson, G. A. 1987. Simulating chemosensory responses of marine microorganisms. Limnol. Oceanogr. 32: 1253-1266.

Jacobson, D. M., and D. M. Anderson. 1986. Thecate hetrotrophic dinoflagellates: feeding behavior and mechanisms. J. Phycol. 22: 249258.

Jaffe, L. F. 1985. The role of calcium explosions, waves, and pulses in activating eggs. Pp. 127-165 in Biology of Fertilization, C. B. Metz and A. Monroy, eds. Academic Press, Orlando, FL.

Jennings, H. S. 1906. Behavior of the Lower Organisms. Columbia University Press, New York.

Johnson, C. H., S. Inoué, A. Flint, and J. W. Hastings. 1985. Compartmentalization of algal bioluminescence: autofluorescence of bioluminescent particles in the dinoflagellate Gonyaulax as studied with image-intensified video microscopy and flow cytometry. J. Cell Biol. 100: $1435-1446$

Jones, D. A., R. J. Keymer, and W. M. Ellis. 1978. Cyanogenesis in plants and animal feeding. Pp. 21-34 in Biochemical Aspects of Plant and Animal Coevolution, J. B. Harborne, ed. Academic Press, London.

Jonsson, P. R. 1986. Particle size selection, feeding rates and growth dynamics of marine planktonic oligotrichous ciliates (Ciliophora: Oligotrichina). Mar. Ecol. Prog. Ser. 33: 265-277.

Jürgens, K., J. Pernthaler, S. Schalla, and R. Amann. 1999. Morphological and compositional changes in a planktonic bacterial community in response to enhanced protozoan grazing. Appl. Environ. Microbiol. 65: $1241-1250$.

Karban, R., and I. T. Baldwin. 1997. Induced Responses to Herbivory. University of Chicago Press, Chicago.

Karl, D. M., ed. 1995. The Microbiology of Deep-Sea Hydrothermal Vents. CRC Press, Boca Raton, FL.

Karsten, U., K. Kück, C. Vogt, and G. O. Kirst. 1996. Dimethylsulfoniopropionate production in phototrophic organisms and its physiological function as a cryoprotectant. Pp. 143-153 in Biological and Environmental Chemistry of DMSP and Related Sulfonium Compounds, R. P. Kiene, P. Visscher, G. Kirst, and M. Keller, eds. Plenum Press, New York.

Keller, M. D., W. K. Bellows, and R. R. L. Guillard. 1989a. Dimethyl sulfide production by marine phytoplankton: an additional impact of unusual blooms. Pp. 101-115 in Novel Phytoplankton Blooms, E. M. Cooper, V. M. Bricelj, and E. J. Carpenter, eds. Springer-Verlag, Berlin.

Keller, M. D., W. K. Bellows, and R. R. L. Guillard. 1989b. Dimethyl sulfide production in marine phytoplankton. Pp. 167-183 in Biogenic Sulfur in the Environment, E. S. Saltzman and W. J. Cooper, eds. American Chemical Society, Washington, DC.

Kiene, R. P. 1993. Measurement of dimethylsulfide (DMS) and dimethylsulfoniopropionate (DMSP) in seawater and estimation of DMS turnover rates. Pp. 601-610 in Handbook of Methods in Aquatic Microbial Ecology, P. F. Kemp, B. F. Sherr, E. B. Sherr, and J. J. Cole, eds. Lewis Publishers, Boca Raton, FL.

Kiene, R. P., P. Visscher, G. Kirst, and M. Keller, eds. 1996. Biolog- ical and Environmental Chemistry of DMSP and Related Sulfonium Compounds, Plenum Press, New York.

Kiersnowska, M., R. K. Peck, and G. de Haller. 1988. Cell to cell recognition between the ciliate Pseudomicrothorax dubius and its food organisms: the role of surface charges. Protoplasma 143: 93-100.

Kirchman, D. L., S. Graham, D. Reish, and R. Mitchell. 1982. Lectins may mediate in the settlement and metamorphosis of Jапиа (Dexiospira) brasiliensis Grube (Polychaeta: Spirorbidae). Mar. Biol. Lett. 3: 131-142.

Kirk, K. L., and J. J. Gilbert. 1992. Variation in herbivore response to chemical defenses: zooplankton foraging on toxic cyanobacteria. Ecology 73: $2208-2217$.

Knoll, A. H., and J. H. Lipps. 1993. Evolutionary history of prokaryotes and protists. Pp. 19-29 in Fossil Prokaryotes and Protists, J. H. Lipps, ed. Blackwell Scientific, Boston.

Knoll, G., B. Haacke-Bell, and H. Plattner. 1991. Local trichocyst exocytosis provides an efficient escape mechanism for Paramecium cells. J. Eur. Protistol. 27: 381-385.

Köhidai, L., and G. Csaba. 1996. Different and selective chemotactic responses of Tetrahymena pyriformis to two families of signal molecules: lectins and peptide hormones. Acta Microbiol. Immunol. Hung. 43: 83-91.

Köhidai, L., P. Kovacs, and G. Csaba. 1994. Chemotactic response of unicellular Tetrahymena to a leukocyte attractant peptide and its repellent derivate: evolutionary conclusions. Cell Biol. Int. 18: 119-122.

Kovács, P., W. E. G. Müller, and G. Csaba. 1997. A lectin-like molecule is discharged from mucocysts of Tetrahymena pyriformis in the presence of insulin. J. Eukaryot. Microbiol. 44: 487-491.

Krembs, C., A. R. Juhl, R. A. Long, and F. Azam. 1998. Nanoscale patchiness of bacteria in lake water studied with the spatial information preservation method. Limnol. Oceanogr. 43: 307-314.

Kuhlmann, H.-W., C. Brünen-Nieweler, and K. Heckmann. 1997. Pheromones of the ciliate Euplotes octacarinatus not only induce conjugation but also function as chemoattractants. J. Exp. Zool. 277: $33-48$.

Kurjan, J., and B. L. Taylor, eds. 1993. Signal Transduction: Prokaryotic and Simple Eukaryotic Systems. Academic Press, San Diego.

Kusch, J. 1993. Behavioural and morphological changes in ciliates induced by the predator Amoeba proteus. Oecologia 96: 354-359.

Kusch, J. 1995. Adaptation of inducible defense in Euplotes daiadaleos (Ciliophora) to predation risks by various predators. Microb. Ecol. 30: 79-88.

Kusch, J. 1999. Self-recognition as the original function of an amoeban defense-inducing kairomone. Ecol. 80: 715-720.

Kusch, J., and H.-W. Kuhlmann. 1994. Cost of Stenostomum-induced morphological defence in the ciliate Euplotes octocarinatus. Arch. Hydro. 130: 257-267.

Lancelot, C., and V. Rosseau. 1994. Ecology of Phaeocystis: the key role of colony forms. Pp. 229-245 in The Haptophyte Algae, J. C. Green and B. S. C. Leadbeater, eds. Clarendon Press, Oxford.

Larsen, A., and L. K. Medlin. 1997. Inter- and intraspecific genetic variation in twelve Prymnesium (Haptophyceae) clones. J. Phycol. 33: 1007-1015.

Leick, V., and P. Hellung-Larsen. 1985. Chemosensory responses in Tetrahymena: the involvement of peptides and other signal substances. J. Protozool. 32: 550-553.

Leigh, R. A., N. Ahmad, and R. G. Wyn Jones. 1981. Assessment of glycinebetaine and proline compartmentation by analysis of isolated beet vacuoles. Planta 153: 34-41.

LeRoith, D., A. S. Liotta, J. Roth, J. Shiloach, M. E. Lewis, C. B. Pert, and D. T. Krieger. 1982. Corticotropin and $\beta$-endorphin-like materials are native to unicellular organisms. Proc. Natl. Acad. Sci. USA 79: 2086-2090. 
Levandowsky, M., and D. C. R. Hauser. 1978. Chemosensory responses of swimming algae and protozoa. Int. Rev. Cytol. 53: 145-210.

Lim, E. L., D. A. Caron, and E. F. Delong. 1996. Development and field application of a quantitative method for examining natural assemblages of protists with oligonucleotide probes. Appl. Environ. Microbiol. 62: 1416-1423.

Lima, S. L. 1998. Nonlethal effects in the ecology of predator-prey interactions. Bioscience 48: 25-34.

Lindstedt, K. J. 1971. Chemical control of feeding behavior. Comp. Biochem. Physiol. 39A: 553-581.

Löfqvist, J. 1976. Formic acid and saturated hydrocarbons as alarm pheromones for the ant Formica rufa. J. Insect Physiol. 22: 1331-1346.

Loomis, W. F., ed. 1982. The Development of Dictyostelium discoideum. Academic Press, New York.

Louis, J. M., C. L. Saxe III, and A. R. Kimmel. 1993. Two transmembrane signaling mechanisms control expression of the cAMP receptor gene CAR1 during Dictyostelium development. Proc. Natl. Acad. Sci. USA 90: 5969-5973.

Lowe, J. B. 1994. Carbohydrate recognition in cell-cell interactions. Pp. 163-205 in Molecular Glycobiology, M. Fukuda and O. Hindsgaul, eds. IRL Press, Oxford.

Luporini, P., A. Vallesi, C. Miceli, and R. A. Bradshaw. 1995. Chemical signalling in ciliates. J. Eukaryot. Microbiol. 42: 208-212.

Machemer, H., and P. F. M. Teunis. 1996. Sensory-motor coupling and motor responses. Pp. 379-402 in Ciliates: Cells as Organisms, K. Hausmann and P. C. Bradbury, eds. Gustav Fischer, Stuttgart.

Mackie, A. M., and P. T. Grant. 1974. Interspecies and intraspecies chemoreception by marine invertebrates. Pp. 105-141 in Chemoreception in Marine Organisms, P. T. Grant and A. M. Mackie, eds. Academic Press, London.

Malin, G., W. H. Wilson, G. Bratbak, P. S. Liss, and N. H. Mann. 1998. Elevated production of dimethylsulfide resulting from viral infection of Phaeocystis pouchetii. Limnol. Oceanogr. 43: 1389-1393.

Manhart, J. R., and R. M. McCourt. 1992. Molecular data and species concepts in the algae. J. Phycol. 28: 730-737.

Margulis, L., and D. Sagan. 1987. Sex: the cannibalistic legacy of primordial androgynes. Pp. 23-38 in The Evolution of Sex, J. M. Smith et al., eds. Harper \& Row, San Francisco.

Margulis, L., J. O. Corliss, M. Melkonian, and D. J. Chapman, eds. 1990. Handbook of Protoctista. Jones and Bartlett, Boston.

Marino, M. J., and D. C. Wood. 1993. $\beta$-endorphin modulates a mechanoreceptor channel in the protozoan Stentor. J. Comp. Physiol. A 172: 233-240.

Mast, S. O. 1906. The reactions of Didinium nasutum (Stein) with special reference to the feeding habits and the function of trichocysts. Biol. Bull. 16: 91-118.

Matoh, T., J. Watanabe, and E. Takahashi. 1987. Sodium, potassium, chloride, and betaine concentrations in isolated vacuoles from saltgrown Atriplex gmelini leaves. Plant Physiol. 84: 173-177.

Matsumura, K. 1995. Tetrodotoxin as a pheromone. Nature 378: $563-$ 564.

McClintock, J. B., B. J. Baker, M. T. Hamann, W. Yoshida, M. Slattery, et al. 1994. Homarine as a feeding deterrent in common shallow-water Antarctic lamellarian gastropod Marseniopsis mollis: a rare example of chemical defense in a marine prosobranch. J. Chem. Ecol. 20: 2539-2549.

Medlin, L. K., G. L. A. Barker, L. Campbell, J. C. Green, P. K. Hayes, et al. 1996. Genetic characterisation of Emiliania huxleyi (Haptophyta). J. Mar. Syst. 9: 13-31.

Mensinger, A. E., and J. F. Case. 1992. Dinoflagellate luminescence increases susceptibility of zooplankton to teleost predation. Mar. Biol. 112: $207-210$.

Mitchell, J. G., A. Okubo, and J. A. Fuhrman. 1985. Microzones surrounding phytoplankton form the basis for a stratified marine microbial ecosystem. Nature 316: 58-59.

Mitchell, J. G., L. Pearson, and S. Dillon. 1996. Clustering of marine bacteria in seawater enrichments. Appl. Environ. Microbiol. 62: 37163721.

Monger, B. C., and M. R. Landry. 1991. Prey-size dependency of grazing by free-living marine flagellates. Mar. Ecol. Prog. Ser. 74: 239-248.

Moore, P. A., D. M. Fields, and J. Yen. 1999. Physical constraints of chemoreception in foraging copepods. Limnol. Oceanogr. 44: 166177.

Müller-Niklas, G., M. Agis, and G. J. Herndl. 1996. Microscale distribution of bacterioplankton in relation to phytoplankton: results from 100-nl samples. Limnol. Oceanogr. 41: 1577-1582.

Nanjundiah, V. 1973. Chemotaxis, signal relaying and aggregation morphology. J. Theor. Biol. 42: 63-105.

Nesbitt, L. M., H. P. Riessen, and C. W. Ramcharan. 1996. Opposing predation pressures and induced vertical migration responses in Daphnia. Limnol. Oceanogr. 41: 1306-1311.

Nevitt, G. 1998. Foraging by seabirds on an olfactory landscape. Am. Sci. 87: 46-53.

Nevitt, G. A. 2000. Olfactory foraging by Antarctic procellariiform seabirds: life at high Reynolds numbers. Biol. Bull. 198: 245-253.

Nevitt, G. A., R. R. Veit, and P. Kareiva. 1995. Dimethyl sulphide as a foraging cue for Antarctic Procellariiform seabirds. Nature 376: $680-682$.

Newman, R. M., Z. Hanscom, and W. C. Kerfoot. 1992. The watercress glucosinolate-myrosinase system: a feeding deterrent to caddisflies, snails and amphipods. Oecologia 92: 1-7.

Nicolas, M.-T., G. Nicolas, C. H. Johnson, J.-M. Bassot, and J. W. Hastings. 1975. Characterization of the bioluminescent organelles in Gonyaulax polyedra (dinoflagellates) after fast-freeze fixation and antiluciferase immunogold staining. J. Cell Biol. 105: 723-735.

Nielsen, T. G., T. Kiørboe, and P. K. Bjørnsen. 1990. Effects of a Chrysochromulina polylepis subsurface bloom on the planktonic community. Mar. Ecol. Prog. Ser. 62: 21-35.

Noordkamp, D. J. B., M. Schotten, W. W. C. Gieskes, L. J. Forney, J. C. Gottschal, and M. van Rijssel. 1998. High acrylate concentrations in the mucus of Phaeocystis globosa colonies. Aquat. Microb. Ecol. 16: 45-52.

O'Day, D. H., ed. 1990. Calcium as an Intracellular Messenger in Eucaryotic Microbes. American Society for Microbiology, Washington, DC.

Oppen, M. J. H. v., H. Klerk, J. L. Olsen, and W. T. Stam. 1996. Hidden diversity in marine algae: some examples of genetic variation below the species level. J. Mar. Biol. Assoc. UK 76: 239-242.

Ortenzi, C., and P. Luporini. 1995. Competition among homologous polypeptide hormones of the ciliate Euplotes raikovi for binding to each other's cell receptors. J. Eukaryot. Microbiol. 42: 242-248.

Pace, N. R. 1997. A molecular view of microbial diversity and the biosphere. Science 276: 734-740.

Paul, V. J., and K. L. van Alstyne. 1992. Activation of chemical defenses in the tropical green algae Halimeda spp. J. Exp. Mar. Biol. Ecol. 160: 191-203.

Peck, R. K. 1985. Feeding behavior of the ciliate Pseudomicrothorax dubius is a series of morphologically and physiologically distinct events. J. Protozool. 32: 492-501.

Peterson, J. B. 1991. Small GTP-binding proteins associated with secretory vesicles of Paramecium. J. Protozool. 38: 495-501.

Plattner, H., R. Stürzl, and H. Matt. 1985. Synchronous exocytosis in Paramecium cells. IV. Polyamino compounds as potent trigger agents for repeatable trigger-redocking cycles. Eur. J. Cell Biol. 36: 32-37.

Plumley, F. G. 1997. Marine algal toxins: biochemistry, genetics, and molecular biology. Limnol. Oceanogr. 42: 1252-1264. 
Pomeroy, L. R. 1992. The microbial food web. Oceanus 35: 28-32.

Popescu, O., and G. N. Misevic. 1997. Self-recognition by proteoglycans. Nature 386: 231-232.

Purcell, E. M. 1977. Life at low Reynolds number. Am. J. Physics 45: 3-11.

Rabinovitch, M., and M. J. De Stefano. 1971. Antibody and plant agglutinins stimulate phagocytosis of erythrocytes by Acanthamoeba. Nature 234: 412-413.

Rapport, D. J., J. Berger, and D. B. W. Reid. 1972. Determination of food preference of Stentor coeruleus. Biol. Bull. 142: 103-109.

Rassoulzadegan, F., and L. Fenaux. 1984. Effect of flavor and size on selection of food by suspension-feeding plutei. Limnol. Oceanogr. 29: 357-361.

Renaud, F. L., I. Colon, J. Lebron, N. Ortiz, F. Rodriguez, and C. Cadilla. 1995. A novel opioid mechanism seems to modulate phagocytosis in Tetrahymena. J. Eukaryot. Microbiol. 42: 205-207.

Ricci, N., A. Morelli, and F. Verni. 1996. The predation of Litonotus on Euplotes: a two step cell-cell recognition process. Acta Protozool. 35: 201-208.

Rittschof, D. 1990. Peptide-mediated behaviors in marine organisms: evidence for a common theme. J. Chem. Ecol. 16: 261-272.

Roberts, D. M., P. Sharp, G. Alderson, and M. A. Collins, eds. 1996. Evolution of Microbial Life. Cambridge University Press, Cambridge.

Rosati, G. 1999. Epixenosomes: symbionts of the hypotrich ciliate $E u$ plotidium itoi. Symbiosis 26: 1-23.

Rosati, G., F. Verni, and P. Lenzi. 1993. "Epixenosomes": peculiar epibionts of the ciliate Euplotidium itoi. The formation of the extrusive apparatus and the ejecting mechanism. Eur. J. Protistol. 29: 238-245.

Rosati, G., G. Petroni, S. Quochi, L. Modeo, and F. Verni. 1999. Epixenosomes: peculiar epibionts of the hypotrich ciliate Euplotidium itoi defend their host against predators. J. Eukaryot. Microbiol. 46: $278-282$.

Rossini, C., A. B. Attygalle, A. González, S. R. Smedley, M. Eisner, J. Meinwald, and T. Eisner. 1997. Defensive production of formic acid $(80 \%)$ by a carabid beetle (Galerita lecontei). Proc. Natl. Acad. Sci. USA 94: 6792-6797.

Saltzman, E. S., and W. J. Cooper, eds. 1989. Biogenic Sulfur in the Environment. ACS, Washington, DC

Sanders, R. W. 1988. Feeding by Cyclidium sp. (Ciliophora, Scutiocociliatida) on particles of different sizes and surface properties. Bull. Mar. Sci. 43: 446-457.

Schaeffer, A. A. 1910. Selection of food in Stentor coeruleus. J. Exp. Zool. 8: 75-132.

Schlenk, F., J. L. Dainko, and G. Svihla. 1970. The accumulation and intracellular distribution of biological sulfonium compounds in yeast. Arch. Biochem. Biophys. 140: 228-236.

Scholin, C. A. 1998. Morphological, genetic, and biogeographic relationships of the toxic dinoflagellates Alexandrium tamarense, A. catenella, and A. fundyense. Pp. 12-27 in NATO Advanced Workshop on the Physiological Ecology of Harmful Algal Blooms, D. M. Anderson, A. M. Cembella, and G. Hallegraef, eds. Springer, Berlin.

Sharon, N., and H. Lis. 1993. Carbohydrates in cell recognition. Sci. Am. 268: 82-89.

Shaw, B. A., P. J. Harrison, and R. J. Anderson. 1995. Feeding deterrence properties of apo-fucoxanthinoids from marine diatoms. II. Physiology of production of apo-fucoxanthinoids by the marine diatoms Phaeodactylum tricornutum and Thalassiosira pseudonana, and their feeding deterrent effects on the copepod Tigriopus californicus. Mar. Biol. 124: 473-481.

Sherr, E. B., and B. F. Sherr. 1991. Planktonic microbes: tiny cells at the base of the ocean's food webs. Trends Ecol. Evol. 6: 50-54.

Sherr, E. B., and B. F. Sherr. 1994. Bacterivory and herbivory: key roles of phagotrophic protists in pelagic food webs. Microb. Ecol. 27: 223-235
Sieburth, J. M. 1960. Acrylic acid, and "antibiotic" principle in Phaeocystis blooms in Antarctic waters. Science 132: 676-677.

Sieburth, J. M. 1961. Antibiotic properties of acrylic acid, a factor in the gastrointestinal antibiosis of polar marine animals. J. Bacteriol. 82: 72-79.

Sieburth, J. M. 1968. The influence of algal antibiosis on the ecology of marine microorganisms. Pp. 63-94 in Advances in Microbiology of the Sea, M. R. Droop and E. J. F. Wood, eds. Academic Press, London.

Sjoblad, R. D., and R. Mitchell. 1979. Chemotactic responses of Vibrio alginolyticus to algal extracellular products. Can. J. Microbiol. 25: 964-967.

Spero, H. J., and M. D. Morée. 1981. Phagotrophic feeding and its importance to the life cycle of the holozoic dinoflagellate, Gymnodinium fungiforme. J. Phycol. 17: 43-51.

Stefels, J., and W. H. M. van Boekel. 1993. Production of DMS from dissolved DMSP in axenic cultures of the marine phytoplankton species Phaeocystis sp. Mar. Ecol. Prog. Ser. 97: 11-18.

Stefels, J., L. Dijkhuizen, and W. W. C. Gieskes. 1995. DMSP-lyase activity in a spring phytoplankton bloom off the Dutch coast, related to Phaeocystis sp. abundance. Mar. Ecol. Prog. Ser. 123: 235-243.

Steinke, M., C. Daniel, and G. O. Kirst. 1996. DMSP lyase in marine macro- and microalgae: intraspecific differences in cleavage activity. Pp. 317-324 in Biological and Environmental Chemistry of DMSP and Related Sulfonium Compounds, R. P. Kiene, P. Visscher, G. Kirst, and M. Keller, eds. Plenum Press, New York.

Steinke, M., G. V. Wolfe, and G. O. Kirst. 1998. Partial characterization of dimethylsulfoniopropionate (DMSP) lyase in 6 strains of Emiliania huxleyi. Mar. Ecol. Prog. Ser. 175: 215-225.

Stoecker, D. K. 1988. Are marine planktonic ciliates suspension-feeders? J. Protozool. 35: 252-255.

Stoecker, D. K. 1992. "Animals" that photosynthesize and "plants" that eat. Oceanus 35: 24-27.

Stoecker, D. K., R. R. L. Guillard, and R. M. Kavee. 1981. Selective predation by Favella ehrenbergii (Tinninnia) on and among dinoflagellates. Biol. Bull. 160: 136-145.

Stoecker, D. K., T. L. Cucci, E. M. Hulbert, and C. M. Yentsch. 1986. Selective feeding by Balanion sp. (Ciliata: Balanioidae) on the phytoplankton that best support its growth. J. Exp. Mar. Biol. Ecol. 95: 113-130.

Stoecker, D. K., S. M. Gallager, C. J. Langdon, and L. H. Davis. 1995. Particle capture by Favella sp. (Ciliata, Tintinnida). J. Plankton Res. 17: 1105-1124.

Strom, S. L. 2000. Bacterivory: interactions between bacteria and their grazers. Pp. 351-386 in Microbial Ecology of the Oceans, D. L. Kirchman and R. Mitchell, eds. John Wiley, London.

Strom, S. L., and H. Loukos. 1998. Selective feeding by protozoa: model and experimental behaviors and their consequences for population stability. J. Plankton Res. 20: 831-846.

Subba Rao, D. V., Y. Pan, and S. J. Smith. 1995. Allelopathy between Rhizosolenia alata (Brightwell) and the toxigenic Pseudonitzschia pungens f. multiseries (Hasle). Pp. 691-686 in Harmful Marine Algal Blooms, P. Lassus, G. Arzul, E. E. Le Denn, P. Gentien, and C. Marcaillou-LeBaut, eds. Lavoisier, Paris.

Sugg, L. M., and R. M. VanDolah. 1999. No evidence for an allelopathic role of okadaic acid among ciguatera-associated dinoflagellates. J. Phycol. 35: 93-103.

Suzaki, E., H. Kobayashi, Y. Kodama, T. Masujima, and S. Terakawa. 1997. Video-rate dynamics of exocytotic events associated with phagocytosis in neutrophils. Cell Motil. Cytoskeleton 38: 215-228.

Sykes, P. F., and M. E. Huntley. 1987. Acute physiological reactions of Calanus pacificus to selected dinoflagellates: direct observations. Mar. Biol. 94: 19-24.

Taniguchi, A., and Y. Takeda. 1988. Feeding rate and behavior of the 
tintinnid ciliate Favella taraikaensis observed with a high speed VTR system. Mar. Microb. Food Webs 3: 21-34.

Tarran, G. A. 1991. Aspects of the grazing behaviour of the marine dinoflagellate Oxyrrhis marina, Dujardin. Ph.D. dissertation, University of Southampton, UK.

Teegarden, G. J., and A. D. Cembella. 1996. Grazing of toxic dinoflagellates, Alexandrium spp., by adult copepods of coastal Maine: implications for the fate of paralytic shellfish toxins in marine food webs. J. Exp. Mar. Biol. Ecol. 196: 145-176.

Thijsse, G. J. E. 1964. Fatty-acid accumulation by acrylate inhibition of $\beta$-oxidation in an alkane-oxidizing Pseudomonas. Biochim. Biophys. Acta 84: 195-197.

Tilney, L. G. 1985. The acrosomal reaction. Pp. 157-213 in Biology of Fertilization, C. B. Metz and A. Monroy, eds. Academic Press, Orlando, FL.

Tollrian, R., and C. D. Harvell, eds. 1999. The Ecology and Evolution of Inducible Defenses. Princeton University Press, Princeton.

Turiff, N., J. A. Runge, and A. D. Cembella. 1995. Toxin accumulation and feeding behaviour of the planktonic copepod Calanus finmarchicus exposed to the red-tide dinoflagellate Alexandrium excavatum. Mar. Biol. 123: 55-64.

Turner, J. T., and P. A. Tester. 1997. Toxic marine phytoplankton, zooplankton grazers, and pelagic food webs. Limnol. Oceanogr. 42: 1203-1214.

Turner, J. T., P. A. Tester, and P. J. Hansen. 1998. Interactions between toxic marine phytoplankton and metazoan and protistan grazers. Pp. 453-474 in NATO Advanced Workshop on the Physiological Ecology of Harmful Algal Blooms, D. M. Anderson, A. M. Cembella, and G. Hallegraef, eds. Springer, Berlin.

Vallesi, A., G. Giuli, R. A. Bradshaw, and P. Luporini. 1995. Autocrine mitogenic activity of pheromones produced by the protozoan ciliate Euplotes raikovi. Nature 376: 522-524.

van den Ende, H. 1985. Sexual agglutination in Chlamydomonas. Adv. Microb. Physiol. 26: 89-123.

Van Donk, E., M. Lürling, D. O. Hessen, and G. M. Lokhorst. 1997. Altered cell wall morphology in nutrient-deficient phytoplankton and its impact on grazers. Limnol. Oceanogr. 42: 357-364.

Van Houten, J. 1994. Chemosensory transduction in eukaryotic microorganisms: trends for neuroscience? Trends Neurosci. 17: 62-71.

Van Houten, J., D. C. R. Hauser, and M. Levandowsky. 1981. Chemosensory behavior in protozoa. Pp. 67-124 in Biochemistry and Physiology of Protozoa, M. Levandowsky and S. H. Hutner, eds. Academic Press, New York.

van Rijssel, M., C. E. Hamm, and W. W. C. Gieskes. 1997. Phaeocystis globosa (Prymnesiophyceae) colonies: hollow structures built with small amounts of polysaccharides. Eur. J. Phycol. 32: 185-192.

Vance, T. C., C. T. Baier, R. D. Brodeur, K. O. Coyle, M. B. Decker, et al. 1998. Aquamarine waters recorded for the first time in eastern Bering Sea. Eos 79: 121.

Verity, P. G. 1988. Chemosensory behavior in marine planktonic ciliates. Bull. Mar. Sci. 43: 772-782.

Verity, P. G. 1991. Feeding in planktonic protozoans: evidence for non-random acquisition of prey. J. Protozool. 38: 69-76.

Verity, P. G., and D. Stoecker. 1982. Effects of Olisthodiscus luteus on the growth and abundance of tintinnids. Mar. Biol. 72: 79-87.
Vogel, G., L. Thilo, H. Schwarz, and R. Steinhart. 1980. Mechanism of phagocytosis in Dictyostelium discoideum: phagocytosis is mediated by different recognition sites as disclosed by mutants with altered phagocytotic properties. J. Cell Biol. 86: 456-465.

von Gersdorff, H., and G. Matthews. 1994. Dynamics of synaptic vesicle fusion and membrane retrieval in synaptic terminals. Nature 367: 735-739.

Wagner, G. J. 1978. Compartmentation in plant cells: the role of the vacuole. Pp. 1-45 in Cellular and Subcellular Localization in Plant Metabolism, L. L. Creasy and G. Hrazdina, eds. Plenum Press, New York.

Waite, A. M., R. J. Olson, H. G. Dam, and U. Passow. 1995. Sugarcontaining compounds on the cell surfaces of marine diatoms measured using concanavalin A and flow cytometry. J. Phycol. 31: 925-933.

Weisse, T., K. Tande, P. Verity, F. Hansen, and W. Gieskes. 1994. The trophic significance of Phaeocystis blooms. J. Mar. Syst. 5: 67-79.

Wesenberg, H., and G. Antipa. 1970. Capture and ingestion of Paramecium by Didinium nasutum. J. Protozool. 17: 250-270.

White, H. H. 1979. Effects of dinoflagellate bioluminescence on the ingestion rates of herbivorous zooplankton. J. Exp. Mar. Biol. Ecol. 36: 217-224.

Wicklow, B. J. 1997. Signal-induced defensive phenotypic changes in ciliated protists: morphological and ecological implications for predator and prey. J. Eukaryot. Microbiol. 44: 176-188.

Windust, A. J., J. L. C. Wright, and J. L. McLachlan. 1996. The effects of the diarrhetic shellfish poisoning toxins, okadaic acid and dinosphysistoxin-1, on the growth of microalgae. Mar. Biol. 126: $19-25$.

Wink, M. 1997. Compartmentation of secondary metabolites and xenobiotics in plant vacuoles. Pp. 141-169 in The Plant Vacuole, R. A. Leigh and D. Sanders, eds. Academic Press, San Diego.

Wolfe, G. V., and M. Steinke. 1996. Grazing-activated production of dimethyl sulfide (DMS) by two clones of Emiliania huxleyi. Limnol. Oceanogr. 41: 1151-1160.

Wolfe, G. V., M. Steinke, and G. O. Kirst. 1997. Grazing-activated chemical defense in a unicellular marine alga. Nature 387: 894-897.

Wolfe, G. V., M. Levasseur, G. Cantin, and S. Michaud. 2000. DMSP and DMS dynamics and microzooplankton grazing in the Labrador Sea: application of the dilution technique. Deep-Sea Res. I. (In press).

Wood, A. M., and T. Leatham. 1992. The species concept in phytoplankton ecology. J. Phycol. 28: 723-729.

Wood, A. M., and L. M. van Valen. 1990. Paradox lost? On the release of energy-rich compounds by phytoplankton. Mar. Microb. Food Webs 4: $103-116$

Wright, S. D., and S. C. Silverstein. 1986. Overview: the function of receptors in phagocytosis. Pp. 41.4-41.14 in Cellular Immunology, L. A. Herzenberg, C. Blackwell, and L. A. Herzenberg, eds. Blackwell Scientific, Oxford.

Zhou, J., and L. Fritz. 1994. Okadaic acid antibody localizes to chloroplasts in the DSP-toxin-producing dinoflagellates Prorocentrum lima and Prorocentrum maculosum. Phycologia 33: 455-461.

Zimmer-Faust, R. K., M. P. de Souza, and D. C. Yoch. 1996. Bacterial chemotaxis and its potential role in marine dimethylsulfide production and biogeochemical sulfur cycling. Limnol. Oceanogr. 41: 1330-1334. 